\title{
Accrual management as an indication of money laundering through legally registered Mafia firms in Italy
}

Authors: Ravenda, Diego; Valencia-Silva, Maika; Argiles Bosch, Josep Maria; Garcia-Blandon, Josep

\begin{abstract}
Purpose - This paper investigates how accounting is used to disguise and realize money laundering activities in specific socio-economic and political contexts and whether discretionary accruals can provide evidence of such illicit practices realized through legally registered Mafia firms (LMFs).

Design/methodology/approach - The study is based on a sample of 224 Italian firms identified as LMFs, due to having been confiscated by judicial authorities because of their owners being accused of Mafia-type association. Using a multivariate regression model, specifically developed discretionary accrual proxies for LMFs are compared with those of a population of lawful firms (LWFs).

Findings - The results reveal that in the pre- and confiscation years, LMFs manage aggregate, revenue and expense accruals in order to smooth earnings and disguise money laundering. In contrast, in the post-confiscation years there is no significant difference in level of accrual management between LMFs and LWFs as a consequence of the intervention of legal administrators.

Originality/value - This study adopts discretionary revenue and expense accrual proxies that provide additional insight into the simultaneous manipulation of revenues and expenses, linked to money laundering, which may not be fully detected by traditional aggregate accrual models. Furthermore, it suggests that the incentive for unlisted LMFs to manage accruals may be fostered by the irrelevance of their financial statements to trades with stakeholders. More importantly, this paper may aid regulators in identifying accounting signals that can be used in risk assessment models or in the detection of criminal practices.
\end{abstract}

Keywords: discretionary accruals; fraud; legally registered Mafia firms; money laundering. 


\section{Introduction}

This paper aims to understand whether accounting information can contribute to understanding the mechanisms of criminal funding and money laundering in specific socio-economic and political contexts. On this matter, Compin (2008) suggests that one of the roles of accounting in a criminal business is to mask the crime by ensuring that the accounting information, although deceptive, contains all the necessary virtues and in turn maintains an impression of rationality and economic credibility. In particular, this study investigates how accounting is used to disguise and realize money laundering activities and whether specifically developed discretionary expense and revenue accruals models, as well as those classical based on aggregate accruals, can provide evidence of such illicit practices realized through legally registered Mafia firms (LMFs). In this regard, according to criminologists' terminology, LMFs are defined as firms that are legally registered and apparently engage in lawful activities but are owned, directly or indirectly (through figureheads), by a Mafia family (Champeyrache, 2004). LMFs differ from lawful firms (LWFs) in three main ways (Gambetta, 1993; Fantò, 1999): the owners are members of a criminal organization; funding may partially or totally come from illegal activities; and criminal methods involving violence, intimidation or corruption are commonly used while doing business. Legal and illegal activities are therefore closely intertwined within LMFs as the legal activities mostly serve to launder profits stemming from illegal ones (Fantò, 1999). Furthermore, criminal methods allow LMFs to benefit from competitive advantages over LWFs (Fantò, 1999; Arlacchi, 2007) and a market power arising from the control of artificially scarce resources (Champeyrache, 2014).

A reliable estimate of the presence of LMFs in Italy is hardly achievable. Nonetheless, the relevance of the phenomenon can be inferred from a recent study, performed by Transcrime (2013) on behalf of Italian Ministry of Interior, which quantifies the annual illegal revenues of Mafias in Italy between 8.3 and 13 billion Euros. Furthermore, $8.7 \%$ of the total investment of Mafias in legal economy between 1983 and 2011 is represented by companies and stocks. On the other hand, prior studies document the infiltration of Italian Mafias in the legal economy of several European countries such as Spain and Germany (Forgione, 2009; Roth, 2009; Transcrime, 2013). Importantly, money laundering practices cannot be exclusively related to Italian Mafia organizations. In this regard, Eurostat (2013) statistical study on money laundering in Europe shows that mostly all European countries have reported money laundering transactions involving firms in recent years. 
The study is based on a sample of 224 Italian firms identified as LMFs, due to having been confiscated at some point by judicial authorities because of their owners being accused of Mafia-type association according to the article 416-bis of the Italian criminal law. More importantly, according to this article, a charge of Mafia-type association entails the automatic confiscation of all the assets of the accused individual, including firms and related shares, which represent the profit of the crime or its investment. After the first instance of court confiscation LMFs are entrusted to one or more legal administrators. The legal administration is an institution designed to reinstate the legality within the confiscated LMFs while fostering their business performance and level of employment. Hence, this paper examines LMFs both before and after their confiscation by comparing them with a population of unlisted LWFs for which there is no evidence of Mafia infiltration. Indeed, a further objective of the study is to assess whether the confiscation of LMFs has a significant impact on their accrual management practices.

Before formulating the hypotheses, the study analyzes previously documented Mafia money laundering practices and the favorable context for LMFs to adopt them according to social theories, borrowed from other disciplines (O’Dwyer and Unerman, 2014; Parker and Guthrie, 2014), describing the influence of the context on corporate illegal behaviors. Subsequently, the authors envisage how these practices may be reflected in discretionary accruals patterns. Overall, the results reveal that in the pre- and confiscation years LMFs manage aggregate, revenue and expense accruals in order to smooth earnings and disguise money laundering. In contrast, in the post-confiscation years there is no significant difference in level of accrual management between LMFs and LWFs, as evidence of the relevant impact of legal administrators' takeover on the accounting practices of LMFs. Furthermore, in the confiscation year LMFs upward manage both revenue and expense accruals with a negative cumulative effect on aggregate accruals and income. Adjustments of prior to confiscation misreporting and the regularization of some transactions carried out by legal administrators may explain these latter results. These conclusions confirm previous findings (Stubben, 2010) on the informative superiority of specific accrual models over aggregate accrual models in detecting a combination of revenue and expense manipulation.

This study can be situated within the academic literature on accrual-based earnings management. In this respect, prior research examines accrual management in varying types of firms and contexts which may have some similarities with the case of LMFs in Italy. In particular, different studies analyze accrual management within: firms committing financial statement fraud (Beneish, 1997; Lee et al., 1999; Jones et al., 2008; Perols and Lougee, 2011), 
firms with political connection (Chaney et al., 2011), socially irresponsible firms (Chih et al., 2008; Gargouri et al., 2010; Kim et al., 2012), unlisted firms (Ball and Shivakumar, 2005; Coppens and Peek, 2005; Burgstahler et al., 2006), family firms in Italy (Prencipe et al., 2008). However, these studies mostly focus on aggregate accruals rather than considering each specific type of accruals. Hence, they do not provide information on how the accrual management is achieved and which underlying practices discretionary accruals may reflect. Conversely, this study adopts specifically developed discretionary revenue and expense accrual proxies that, compared to aggregate accrual models, provide additional insight into the simultaneous manipulation of revenues and expenses, linked to money laundering activities. Furthermore, although some traits of LMFs can be identified in the aforementioned studies on accrual management, this study contributes to the accounting literature given that, to the best of authors' knowledge, it is the first that specifically seeks to relate accrual management to money laundering activities within the context of LMFs. These unlisted firms may particularly interest the scientific community due to their singularities. Indeed, they are socially irresponsible by nature and their incentives, operating context and modus operandi differ from those of listed companies. In particular, this study suggests that the incentive of unlisted firms such as LMFs to engage in accrual management for illicit purposes increases whether specific competitive advantages or a dominant market position make their financial statements irrelevant for trading with stakeholders. Finally, this paper may aid practitioners and regulators in identifying accounting signals that can be used in risk assessment models or in the detection of criminal infiltrations and related illicit practices, especially in contexts similar to that of LMFs.

The remainder of the paper proceeds as follows: section 2 reviews the literature and develops the hypotheses; section 3 describes the research design and sample data; section 4 presents empirical results; section 5 includes discussions and concluding remarks.

\section{Theoretical background and hypothesis development}

\subsection{Legally registered Mafia firms: operating context and theory}

One of the main reasons for criminal organizations to take on new businesses is to be able to invest and launder significant financial resources coming from illegal activities, such as usury, extortion, drug, waste and arms trafficking and so on. In this way, criminal organizations achieve high profits, power and social consensus by ensuring employment and income for the population in the areas where they exercise control of the territory (Fantò, 1999; Riccardi, 2014; Sciarrone, 2014). Fantò (1999) suggests that the main trait of LMFs is not the type of business 
run but the nature of the capital accumulation process that leads to their formation as well as the strength of intimidation on which they are hinged. In particular, the mafia-style intimidation is a source of surplus value and competitive advantages of LMFs over LWFs. In this regard, Arlacchi $(1983,2007)$ identifies the following competitive advantages of the LMFs over the LWFs: discouragement of competition (securing goods and raw materials at favorable prices, as well as orders, contracts and commercial outlets using criminal intimidation); wage compression (evasion of social security contributions and insurance, non-payment of overtime, denial of trade union rights); availability of financial resources (investment of huge proceeds coming from illegal activities without bearing the cost of credit).

Economic, social, political and institutional context is favorable for LMFs to thrive and engage in fraudulent practices. In particular, the influence of the context is implicit in a model, usually defined as fraud triangle, in which illegal corporate behaviors are attributable to the interactive effects of motivation or pressure to engage in corporate illegality, the provision of opportunities for it to occur (e.g. ineffective control), and the personal attitudes (ethical values) allowing the rationalization of the dishonest act (McKendall and Wagner, 1997; Wilks and Zimbelman, 2004; Cohen et al., 2010; Morales et al., 2014; Soltani, 2014). These fraud triggering factors could be identified in LMFs. Indeed, LMFs may be a means of Mafiosi owner-managers to launder dirty money and achieve profits by engaging in illegal practices, under the protection of the criminal organization granting competitive advantages over LWFs. Rationalization processes for the self-justification of illegal behaviors may also occur among employees (Cohen et al., 2010) who may also be pressured because of their dependence on LMFs for their livelihood in economically depressed Southern Italian regions, where LMFs are mostly located. In this regard, a power of Mafiosi owners, based on the control of scarce economic resources, can be identified as a context feature that supports illegal practices within LMFs as well as their development (Lukes, 2005; Palmer, 2012).

In particular, Champeyrache (2014) proposes an institutional theory supporting artificial scarcity (Veblen, 1915, 1921) as the functioning principle of LMFs. This means that Mafia organizations use LMFs to voluntarily and collectively create an imbalance between supply and demand (scarcity) in markets they infiltrate, in order to dominate decollectivized non-mafiosi individuals (Dugger, 1989). More specifically, LMFs create artificial scarcity by controlling and restricting to individuals outside their criminal network the access to resources and final goods in the territories under their sovereignty. At the same time, the economic power granted by artificial scarcity fosters the social status and the mystification of Mafia organizations which allow LMFs to gain social legitimacy (Dugger, 1980). Indeed, non-mafiosi interpret these 
barriers to accessing goods as a restriction due to their lack of inclusion in the upper strata, creating an incentive to emulate LMFs and abide by mafia rules to access goods (Champeyrache, 2014). In particular, LMFs use their competitive advantages (e.g. superior access to liquidity) and other criminal methods to take over strategic sectors (e.g. raw material market and public procurement) and establish monopolistic high prices for scarce resources which prevent would-be and existing entrepreneurs from freely developing activities and individual talents (Arlacchi, 2007). Furthermore, LMFs consolidate their market power by expelling non-mafiosi entrepreneurs from infiltrated markets or taking control of their firms using direct violence and/or asphyxiation through usurious loans (Masciandaro, 1997; Champeyrache, 2004). Specifically, Mafia organizations are able to benefit from situations of economic crisis, by offering financial resources to entrepreneurs who have difficulty in accessing credit, or by taking over troubled businesses as fronts for money laundering (Riccardi, 2014; Sciarrone and Storti, 2014). The tendency of LMFs to establish a monopoly power is consistent with previous studies, finding that the sectors more vulnerable to Mafia infiltration are characterized by low technological level, high labor and cash intensity, predominance of small-medium enterprises that compete on the local market (e.g. construction), low international competition and strong public regulation (e.g. competitive bidding) which allows the Mafia to put pressure on policy-makers and gain advantageous positions in accessing public resources (Daniele and Marani, 2008; Lavezzi, 2008; Riccardi, 2014; Sciarrone and Storti, 2014).

On the other hand, other studies focus on the influence of the institutional context upon corporate illicit practices (Misangyi et al., 2008; Cooper et al., 2013; Gabbioneta et al., 2013). In this regard, unlike other forms of organized crime for which making a profit is the primary goal (Finckenauer, 2005), the Mafia is not oriented exclusively towards profit-making, but also seeks power (Sciarrone, 2014). Indeed, Mafia organizations can be regarded as politicoinstitutional authorities that seek political control of the territories where they are established by sharing forms of government and governance with the state and local authorities (Catanzaro, 1985; Mattina, 2011). In this respect, Dickie (2004, pp. 67-78) asserts that the central political authorities of Italy have repeatedly relied on the Mafia to serve as an instrument of local government during periods of turmoil in Sicilian history. It can be inferred that the development of Mafia-type activities is more likely in weak governance contexts where political institutions are absent or have failed to enforce rules regulating economic processes and protecting property rights (Catanzaro, 1985; Gambetta, 1993; Venkatesh, 1997). In addition, ineffective institutions 
foster corrupt practices and the private appropriation of public resources which may result in a widespread lowering of the sense of legality (Della Porta and Vannucci, 2011).

The infiltration of Mafia organizations in political institutions is mainly achieved by distorting electoral outcomes and intervening in the market for votes (Buonanno et al., 2016). In particular, Mafia organizations procure votes to politicians (through either threats or rewards to citizens) in exchange for favors represented by diversion of public funds and procurement contracts, favorable legislation and lenient prosecution (Gambetta, 1993). Importantly, the deep infiltration of Mafia organizations in public and political institutions and the weak legality culture of their members may undermine the 'arm's length' social distance required for independent scrutiny and appraisal (Westphal and Clement, 2008; Gabbioneta et al., 2013). This situation may offer a fertile institutional context not only for illicit behaviors with a relatively low risk of detection but also for LMFs to thrive and expand (Gond et al., 2009). In this respect, various sociological studies and investigations by judicial authorities show the capacity of LMFs to take part in the processes by which contracts for public works are awarded, through both their capacity for intimidation and the control they exert over local authorities (Capacchione, 2008; Di Fiore, 2008; Anselmo, 2009). Above and beyond capitalist accumulation, this capacity to dominate markets and carry out works gives Mafia organizations a high degree of political and institutional legitimacy, shared with the authorities, due to the greater importance now given to private enterprise in establishing and delivering public policy in mechanisms of territorial governance (Mattina, 2011).

Finally, institutional theories state that regulatory scrutiny is dampened to the extent that an organization achieve an institutional ascription of probity by openly conforming to social expectations, although only symbolically (Bromley and Powell, 2012; Gabbioneta et al., 2013). In particular, LMFs meet social expectations and gain social consensus and support by redistributing revenues and providing employment in depressed Southern Italian regions (Gambetta and Reuter, 1995; Calderoni and Riccardi, 2011). Hence, this support from at least some of the local population may protect LMFs and discourage local authorities' inspections and interventions even in case of suspicions of illicit practices. In this respect, Sciarrone (1998) asserts that Mafia organizations have a social capital of relations within civil society, the political world, and local populations due to their ability to form social networks and relationships, to set up exchanges, create ties of trust, exchange and favors, and establish reciprocal duties. These socio-territorial roots and the construction of a capital of social relations are a primary underlying reason for the persistence of Mafias. 


\subsection{Definition of discretionary accruals proxies}

Prior studies use a wide variety of discretionary accruals $(D A C)$ measures as surrogates for accrual management (Jones, 1991; Subramanyam, 1996; DeFond and Subramanyam, 1998; Kothari et al., 2005). However, these studies mostly focus on aggregate accruals rather than considering each specific type of accruals. In this regard, previous research questions aggregate accrual models for providing biased and noisy estimates of discretion (Dechow et al., 1995; Bernard and Skinner, 1996; Stubben, 2010). Furthermore, McNichols and Wilson (2000) suggest that future progress in the accrual management literature is more likely to come from the examination of specific accruals. In confirmation of this, in a recent study Stubben (2010), using a sample of firms subject to SEC enforcement actions for a mix of revenue- and expense related misstatements, finds that revenue accrual models are more likely than aggregate accrual models to detect a combination of revenue and expense manipulation, especially in growth firms. Hence, following previous research (Caylor, 2010; Stubben, 2010; Capalbo et al., 2014), this study uses discretionary revenue accruals (DREV) to measure revenue accrual management as well as discretionary aggregate accruals $(D A C)$ to measure aggregate accrual management. In addition, the authors build a new measure of discretionary expense accruals (DEXP) to measure expense accrual management. In essence, the authors consider that LMFs may resort to a combination of revenue and expense manipulation, for example through fictitious transactions, in order to achieve their illicit purposes. As manipulation of revenues and expenses can be performed in the same direction, increasing revenues and expenses or vice versa, the total effect may not be detected in discretionary aggregate accrual models that do not provide information as to which components of earnings firms manage and how the accrual management is achieved (Marquardt and Wiedman, 2004; Stubben, 2010). Moreover, unlike other specific accruals (e.g. allowance for bad debts, depreciations, etc.), revenue and expense accruals are common across industries and represent a large portion of the earnings discretion available to firms (Stubben, 2010). Finally, similar to previous studies (Warfield et al., 1995; Klein, 2002; Kim et al., 2012), this paper initially employs the unsigned value of the aforementioned accrual management proxies. Indeed, accrual management can be either income-increasing or income-decreasing and the authors do not have reasons for expecting any of them to be prevalent within LMFs in the long-term. 


\subsection{Accrual management within LMFs and hypothesis formulation}

Prior to carrying out this research the authors expect higher accrual management intensity within LMFs before confiscation relative to LWFs. These expectations are based both on the characteristics of LMFs and on some previous studies examining firms with similarities in certain aspects. In particular, prior studies assume that accrual management is mostly performed to boost earnings rather than reducing them, mainly because they analyze listed companies (e.g. Cohen et al., 2008; Cohen and Zarowin, 2010; Badertscher, 2011; Kim et al., 2012; Zang, 2012). On the other hand, this study examines unlisted firms whose incentives and accrual management patterns may differ from those of listed companies. Indeed, previous studies identify tax avoidance as a primary incentive for accrual management in unlisted firms, especially in countries with strong alignment of financial and tax accounting (Ball and Shivakumar, 2005; Burgstahler et al., 2006; Goncharov and Zimmermann, 2006; Van Tendeloo and Vanstraelen, 2008; Marques et al., 2011). In particular, in these countries, including Italy (Alford et al., 1993; Hung, 2000; Coppens and Peek, 2005), firms prefer low volatility in earnings (Ball et al., 2000; Coppens and Peek, 2005). Indeed, third-party effect, in the form of tax demanded by tax authorities, makes communication with stakeholders costly and can be interpreted as a breakdown of the revelation principle assumption justifying the benefit of income-decreasing accrual management (Arya et al., 1998, 2003; Walker, 2013). It is worth mentioning that the financial statements of the unlisted firms of this study are prepared according to the same legally defined Italian GAAP. Indeed, the Italian legislative decree $\mathrm{n}$. 38/2005 requires the adoption of IFRS only for the listed companies, without the option for the unlisted firms to similarly adhere to IFRS. In particular, Italian GAAP are significantly affected by tax considerations given that for example taxable deductible expenses should necessarily be recorded in the income statement and the accounting income is the basis for the calculation of the taxable income.

On the other hand, the use of financial statements in contracting with stakeholders (e.g. banks, customers, suppliers, employees) reduces incentives for unlisted firms to engage in accrual management for tax avoidance purposes (Klassen, 1997; Beatty and Harris, 1999; Coppens and Peek, 2005). Indeed, an income-decreasing accrual management may negatively affect the terms of trades with the aforementioned stakeholders as well as resulting in other negative consequences, including larger costs of debt and equity or a higher likelihood of a lawsuit (Francis et al., 2005; Ibrahim et al., 2011). In this regard, based on a survey of U.S. financial executives, Dichev et al. (2013) find that the earnings management motivations to avoid violation of debt covenants and influence non-capital stakeholders are much stronger for 
unlisted firms, relative to listed firms, consistent with lower dependence on capital markets and more emphasis on contractual considerations. Nonetheless, LMFs can usually count on financial resources coming from illegal activities which reduce the need for bank financing and the related incentive to report a positive financial performance or an acceptable accrual quality. This latter incentive is further weakened because of the usage of criminal methods such as intimidation and bribing to obtain favorable terms in trades with other stakeholders such as suppliers, customers, and employees. Hence, LMFs do not have to face trade-offs in their financial and tax reporting decisions.

Assuming tax avoidance as a main incentive for LMFs to engage in accrual management, the authors expect LMFs to prefer small profits to large profits as well as a low volatility in earnings. Indeed, avoiding high earnings reduces taxes and avoiding persistent low/negative earnings reduces the probability of being investigated by the tax authorities (Herrmann and Inoue, 1996; Coppens and Peek, 2005). Hence, LMFs may use discretionary accruals to sustainably smooth earnings over a long period. These considerations lead to the first hypothesis of this study:

\section{H1a: in the pre-confiscation years LMFs smooth earnings through discretional accruals more than LWFs do.}

Money laundering, a raison d'être for LMFs, is a structured activity aiming to conceal the illegal source of criminal proceeds by disguising them as lawful earning. Three basic money laundering stages can generally be identified: placement, layering and integration (Gilmore, 1999; Buchanan, 2004; He, 2010). Placement is the process of introducing the proceeds from illegal activities into the financial system in a way that government authorities are not able to detect. Layering is the process of generating complex financial transactions to distance the funds from their point of criminal origin and ownership. Finally, integration is the conversion of the illegal proceeds into apparently legitimate business earnings through normal financial or commercial operations.

The money laundering stages in which LMFs are engaged may depend on their activities and characteristics. Specifically, the set-up or acquisition of a firm by Mafia members can be realized with proceeds of illicit activities and be part of the money laundering integration stage. However, LMFs can also be involved in the other two stages. In particular, Martocchia et al. (2014) examine several cases of LMFs engaging in the so called trade-based money laundering which is among the most used layering technique (Maitland Irwin et al., 2012). The Financial 
Action Task Force (2006) defines trade-based money laundering as: the process of disguising the proceeds of crime and moving value through the use of trade transactions in an attempt to legitimize their illicit origins. More specifically, first LMFs get public contracts awarded using bribery, intimidation and other forms of influence over the public administration and especially over local public officials and politicians (Caneppele et al., 2009; Savona, 2010). Subsequently, LMFs use false or inflated invoicing for work not performed or material not used or not meeting specifications, in order to create business expense records and to transfer cash to colluded parties that subsequently kick the money back to the Mafia organizations and/or corrupt public officials. Trade-based money laundering is strictly linked to tax avoidance practices given that the misrepresentation of value of trade transactions has a direct effect on value added tax and income tax.

Money laundering through cash intensive businesses (Gilmour and Ridley, 2015) is a further method used to deposit illicit cash into the banking sector (placement). In this method, a business typically expected to receive a large proportion of its revenue as cash uses its accounts to deposit criminally derived cash, as well as legitimate cash, by falsifying receipts and invoices (Fantò, 1999; Fiorentini, 1999). LMFs of cash-intensive sectors (e.g. retail stores, convenience stores, hotels, restaurants, etc.) may be involved in the placement stage of money laundering. This practice may be particularly typical for long-live LMFs permanently established in the territory which have managed to gain a social consensus and a consolidated banking profile (Levi and Reuter, 2006; Gilmour and Ridley, 2015). Another money laundering placement technique, commonly adopted by LMFs, is based on the payment of "black salaries" to employees using dirty money (Caneppele et al., 2009; Martocchia et al., 2014).

The aforementioned money laundering practices within LMFs may be realized through transaction management affecting cash flow from operations (CFO) during the fiscal year and resulting in abnormal expense and revenue patterns showed in their financial statements. In this regard, in the survey conducted by Graham et al. (2005), financial executives of U.S. listed companies express a preference for managing earnings through real transactions affecting $\mathrm{CFO}$ rather than through accruals. However, a wider usage of accruals can be assumed in LMFs relative to listed firms. In particular, accrual management may be a necessary complement of transaction management carried out through false trade documents in order to disguise money laundering (Caneppele et al., 2009; Martocchia et al., 2014; Gilmour and Ridley, 2015). Indeed, discretionary accruals may allow adjusting abnormal and fraudulently manipulated expenses/revenues at year end, while keeping an impression of rationality and economic credibility of the accounting information (Compin, 2008). Hence, a more intensive accrual 
management within LMFs may be the natural consequence of opportunistically manipulated accounting information that does not reflect the patterns of a standard business activity.

Moreover, the authors expect a higher level of accrual management for LMFs due to the low level of scrutiny from outsiders of these firms compared to the LWFs, in connection with the protection ensured by their criminal ties and infiltrators in all spheres of political and institutional life of the country. Indeed, previous studies find that a low external monitoring intensity is associated with a higher level of accrual management (Duellman et al., 2013; Wongsunwai, 2013). In particular, some analogy may be found with the case of politically connected firms studied by Chaney et al. (2011) which exhibit higher accrual management than firms lacking such connections. Similar to politically connected firms, to the extent that organized crime provides protection to LMFs so that low quality accounting information is not penalized, LMFs might simply care less about the quality of the information they disclose and invest less time to accurately portray their accruals (Chaney et al., 2011). In this case, the quality of information would be low due to inattention on the part of the firm's managers. In addition, lack of managerial competencies may also negatively affect the quality of accounting information. Indeed, in LMFs allegiance to the Mafia family may be considered as the essential criterion for appointing future agents often recruited from a relatively small pool of affiliates and trustees (Duplat et al., 2012). Conversely, in LWFs the selection process is largely driven by the skills and abilities of these candidates to run the business. Based on previous considerations, this study empirically tests the following research hypotheses:

\section{Relative to LWFs, in the pre-confiscation years LMFs engage more in:}

\section{H2a: aggregate accrual management;}

\section{H3a: revenue accrual management;}

\section{H4a: expense accrual management.}

After confiscation most of the LMFs fall into financial distress and often end up in liquidation (ANBSC, 2012). The main reasons for that may be: the loss of privileged and illegal business opportunities, the increase in operating expenses (e.g., regularization of undeclared workers and increase in service expenses for external support) and the shortage of funding given that the dirty money flow is interrupted and the banks are more reluctant to grant credit. In this respect, previous studies find that distressed firms prior to bankruptcy engage in incomeincreasing accrual management in order to conceal the deteriorating financial conditions until they improve (Smith et al., 2001; Rosner, 2003; Charitou et al., 2007; García Lara et al., 2009). 
More importantly, after the confiscation one of the tasks of legal administrators is the reinstatement of legality within LMFs. Hence, accounting adjustments, including accrual reversals, to correct previous misreporting and the regularization and settlement of some transactions may still lead to higher accrual management measures relative to LWFs in the year of confiscation, although for different reasons from those prior to confiscation. In particular, earnings smoothing and money laundering concealing may no longer be the main incentives. Therefore, the further hypotheses of this study are:

H1b: in the confiscation year there is no significant difference between LMFs and LWFs in level of earnings smoothing through discretionary accruals.

Relative to LWFs, in the confiscation year LMFs engage more in:

H2b: aggregate accrual management;

H3b: revenue accrual management;

H4b: expense accrual management.

In contract, in the years following the confiscation year the authors expect practices of LMFs to be more aligned to those of LWFs with no significant difference in their degree of accrual management. Hence, the final hypotheses of the study are:

In the post-confiscation years there is no significant difference between LMFs and LWFs in level of:

H1c: earnings smoothing through discretionary accruals;

H2c: aggregate accrual management;

H3c: revenue accrual management;

H4c: expense accrual management.

\section{Methodology}

\subsection{Data and sample selection}

LMFs sample consists of 224 firms confiscated to organized crime, some of them provided by National Agency for the Management and Assignment of Seized and Confiscated Assets (ANBSC) and others found in online newspapers and AIDA database. ANBSC is the national body currently in charge of the management and assignment of assets, including firms, seized and confiscated to Mafia organizations by Italian judicial authorities. It is noteworthy that the sample size is acceptable if compared with that of other studies on financial statement fraud 
(e.g. Beneish, 1997; Lee et al., 1999, Jones et al., 2008; Perols and Lougee, 2011). The financial statements for all firms are obtained from AIDA, the Italian Bureau Van Dijk database. It contains comprehensive information on 1 million companies with a turnover above $€ 500,000$ in Italy, including the indication for some of them of the confiscation status and date of confiscation. Only 54 out of 1,663 firms provided by ANBSC have financial statements available on AIDA, mostly because of their small size. In addition, the authors include firms confiscated in first instance found on AIDA database (118) and online newspapers (52) until reaching a total of 224. For the 224 LMFs the authors obtain from AIDA available financial statement data for the year of confiscation and for the years prior to and following the confiscation within the period from 2003 to 2012. The authors then estimate the base regression model of Eq. (7) including LMF-years and AIDA population of active unlisted firm-years from 2003 to 2012 in LMFs industries. This study initially avoids the matched sample procedure because of the concerns on its validity raised by Cram at al. (2009). However, the base regression model includes control variables for year, size and two-digit industry SIC code. Table 1 summarizes the sample selection procedure that yields the 224 LMFs and the 78,340 LWFs.

\section{(Insert Table 1 approximately here)}

Table 2 presents the industry distribution by two-digit SIC groups of LMFs in the sample and AIDA population of active unlisted firms with available financial data from 2003 to 2012 in the same industries as the LMFs.

\section{(Insert Table 2 approximately here)}

Compared to the population of active and unlisted firms on AIDA with available financial data from 2003 to 2012, the sample LMFs are especially more abundant in industry groups: building construction-general contractors and operative builders (18.30\% of LMFs sample versus $7.00 \%$ of population), food stores (7.14\% versus $2.22 \%)$ and Motor freight transportation and warehousing (8.04\% versus 3.69\%). On the other hand, there is a lower proportion of LMFs mostly in wholesale trade, durable goods $(10.27 \%$ versus $17.95 \%)$, business services $(0.89 \%$ versus $6.38 \%$ ) and fabricated metal products, except machinery and transportation equipment ( 0.89 versus $8.98 \%$ ). It is noteworthy that Construction (SIC codes $15-17$ ) is the sector with the highest cumulative percentage (23.21\%) of LMFs in the sample. Indeed, construction is a sector with a high concentration of public contracts whose control represents a relevant business for Mafia organizations (Caneppele et al., 2009; Savona, 2010). Wholesale Trade (SIC codes 5051 ) is the second most representative sector (18.75\%) in LMFs sample, followed by Transportation \& Public Utilities (SIC codes 42-49 - 13.41\%) and Retail Trade (SIC codes 52- 
$59-12.96 \%)$. These latest sectors are cash-intensive and/or supply cash-intensive businesses which are particularly suitable for depositing illicit cash into the banking sector (Gilmour and Ridley, 2015). Furthermore, Wholesale and Retail Trade sectors include a wide range of subsectors that can be exploited for illegal activities of different kinds, such as counterfeiting (e.g. in the case of the wholesale and retail trade of clothing and textiles) or drugs trafficking (e.g. in the case of import/export companies) (Lo Bello, 2011; Savona and Riccardi, 2015). Cumulatively, the industry distribution of LMFs in the sample is consistent with previous studies that find LMFs mostly concentrated in sectors characterized by scant openness to foreign investments, low-tech industries, cash- and labor-intensiveness, small-medium enterprises, strong deregulation, high territorial distinctiveness, and high involvement of public resources and public authorities (Savona, 2015).

\subsection{Accrual management proxies (dependent variables)}

In order to test the hypotheses, the authors need to build the measures of discretionary accruals to input as dependent variables in the base regression model. Hence, they calculate $D A C$ as the residuals from the following Eq. (1) based on the modified Jones model (Dechow et al., 1995) with a control for performance (Kothari et al., 2005). Its parameters are estimated crosssectionally for each industry-year with at least 15 observations:

$$
\frac{A C C R_{t}}{T A_{t-1}}=\beta_{0}+\beta_{1} \frac{1}{T A_{t-1}}+\beta_{2} \frac{\Delta R E V_{t}-\Delta A R_{t}}{T A_{t-1}}+\beta_{3} \frac{P P E_{t}}{T A_{t-1}}+\beta_{4} R O A_{t-1}+\varepsilon_{t}
$$

Where in year $\mathrm{t}$ (or $\mathrm{t}-1$ ), ACCR denotes total accruals; TA, $\triangle R E V, \triangle A R, P P E$, and ROA represent total assets, changes in net revenue, changes in accounts receivables, property, plant, and equipment, and return on assets, respectively. Consistent with previous studies on accrual management (Jones, 1991; Dechow et al., 1995; Bergstresser and Philippon, 2006), ACCR are computed as:

$$
A C C R_{t}=\Delta C A_{t}-\Delta C L_{t}-\Delta C A S H_{t}+\Delta S T D_{t}-D E P_{t}
$$

Where:

$\triangle C A=$ change in current assets; $\triangle C L=$ change in current liabilities; $\triangle C A S H=$ change in cash and cash equivalents; $\triangle S T D=$ change in debt included in current liabilities; $D E P=$ depreciation and amortization expenses.

In the estimations of Eq. (1) the authors use all active firms in AIDA (excluding LMFs) which are not listed on the stock exchange and with financial statements available for 10 years from 2003 to 2012. The total number of these firms at the moment of its retrieval from AIDA is 78,340 . 
Similar to Stubben (2010) and Caylor (2010), the authors calculate discretionary revenue accruals (DREV) as the residuals from the following Eq. (3) estimated in the same way as Eq. (1). In line with Caylor (2010), this paper assumes that changes in accounts receivables are positively related to future changes in cash flow from operations $(C F O)$ as well as contemporaneous changes in revenues, since the receivable amounts will be collected in the next period:

$$
\frac{\Delta A R_{t}}{T A_{t-1}}=\beta_{0}+\beta_{1} \frac{1}{T A_{t-1}}+\beta_{2} \frac{\Delta R E V_{t}}{T A_{t-1}}+\beta_{3} \frac{\Delta C F O_{t+1}}{T A_{t-1}} \varepsilon_{t}
$$

As the statement of CFO is not legally required for unlisted firms in Italy, $C F O$ is computed as: earnings before tax $-A C C R$.

Following the same rationale as $D R E V$ the authors additionally calculate discretionary expense accruals (DEXP) as the residuals from the following Eq. (4) estimated in the same way as Eq. (1):

$$
\frac{\Delta A P_{t}-\Delta I N V_{t}}{T A_{t-1}}=\beta_{0}+\beta_{1} \frac{1}{T A_{t-1}}+\beta_{2} \frac{\Delta R E V_{t}}{T A_{t-1}}+\beta_{3} \frac{\Delta C F O_{t+1}}{T A_{t-1}} \varepsilon_{t}
$$

Where $\triangle A P$ and $\triangle I N V$ represent change in accounts payables and change in inventory, respectively.

It is noteworthy that positive $D E X P$ result in an income-decreasing effect due to a discretionary increase of payable invoices $(\triangle A P)$ at year end which is not offset by a corresponding discretionary increase in inventory $(\Delta I N V)$. The situation is exactly the opposite in case of negative $D E X P$.

Finally, following Ghosh and Olsen (2009), the authors measure earnings smoothing $(S M T H)$ through discretionary accruals as the volatility, variance $\left(\sigma^{2}\right)$, of pre-managed earnings relative to the volatility of reported (managed) earnings both deflated by lagged total assets:

$$
S M T H=\sigma^{2} \text { pre-managed earnings }-\sigma^{2} \text { reported earnings }
$$

Where pre-managed earnings are computed as: reported earnings - DAC.

The authors calculate the variances using rolling time intervals of three years in order to minimize the loss of observations. Furthermore, the authors standardize SMTH within each industry-year (two-digit SIC). If discretionary accruals are used to reduce the volatility of reported earnings, then this latter should be less than the volatility of pre-managed earnings. Hence, larger values of SMTH indicate more intensive earnings smoothing. 


\subsection{Control variables and base regression model}

As independent variables strictly related to the hypotheses the authors use binary variables $L M F \_P R E C O N F$ taking value of 1 for pre-confiscation LMF-years, $L M F \_C O N F$ taking value of 1 for LMF-years in the confiscation year, LMF_POSTCONF 1 taking value of 1 for LMFyears in the first year after confiscation year, $L M F \_P O S T C O N F 2$ taking value of 1 for all the following post-confiscation LMF-years and $L W F$ taking value of 1 for LWF-years. The latter is excluded from the final regression model as a base variable. Furthermore, this study considers other control variables shown in the prior literature to be associated with accrual management (e.g. Klein, 2002; Roychowdhury, 2006; Cohen and Zarowin, 2010; Gunny, 2010; Badertscher, 2011; Kim et al., 2012; Zang, 2012; Zhao et al., 2012; Alissa et al., 2013; Duellman et al., 2013;). Specifically, the authors include absolute change in net income (ABSANI), size (SIZE), long-term indebtedness ( $L E V L O N G)$, sum of inventory and receivables (INVREC), assets growth (GROWTH), financial performance (ROA), and an indicator variable for firms reporting losses (LOSS). Furthermore, the authors include the current effective tax rate (ETR) (Hanlon and Heitzman, 2010; Lanis and Richardson, 2012) consistent with the stronger tax avoidance incentive in unlisted firms. The authors also consider the case of firms just meeting zero earnings benchmark that previous studies find to be more likely to engage in income-increasing accrual management (Roychowdhury, 2006; Gunny, 2010; Zang, 2012). In particular, Coppens and Peek (2005) and Burgstahler et al. (2006) find that unlisted firms of several European countries, including Italy, avoid reporting small losses. Therefore, the authors indicate as suspect (SUSPECT) firm-years with earnings before tax over lagged assets greater than or equal to zero but less than 0.01 (Gunny, 2010). Previous research documents that firms use a mix of earnings management techniques and trade-off between them based on their relative costs (Cohen et al., 2008; Cohen and Zarowin, 2010; Badertscher, 2011; Zang, 2012). Hence, the authors include a proxy for real earnings management represented by abnormal material expenses (ABMAT). Based on prior studies (e.g. Roychowdhury, 2006; Cohen et al., 2008; Kim et al., 2012), it is calculated as the residuals from the following Eq. (6) whose parameters are estimated similarly to Eq. (1):

$$
\frac{M A T_{t}}{T A_{t-1}}=\beta_{0}+\beta_{1} \frac{1}{T A_{t-1}}+\beta_{2} \frac{S_{t}}{T A_{t-1}}+\beta_{3} \frac{\Delta S_{t}}{T A_{t-1}}+\beta_{4} \frac{\Delta S_{t-1}}{T A_{t-1}}+\varepsilon_{t}
$$

Where in year $\mathrm{t}$ (or $\mathrm{t}-1), M A T_{t}$ are material expenses including both raw materials and trading goods; $T A, \mathrm{~S}_{\mathrm{t}}$, and $\Delta \mathrm{S}_{\mathrm{t}}$ respectively represent total assets, net sales and change in net sales relative to previous year. Furthermore, the authors add variable REVTA (revenues divided by total assets), standardized by industry and year, whose abnormally high or low values may 
provide indication of revenue manipulation (Fanning and Cogger, 1998; Perols and Lougee, 2011), which may be associated with accrual management.

Finally, the authors include dummy variables representing industry (INDSEC) and year (YEAR). In summary, to test the hypotheses the following base regression model is estimated for the accrual management proxies:

$$
\begin{aligned}
& A M_{-} P R O X Y_{t}=\beta_{0}+\beta_{1} L M F_{-} P R E C O N F_{t}+\beta_{2} L M F_{-} C O N F_{t}+\beta_{3} L M F_{-} P O S T C O N F 1_{t}+ \\
& \beta_{4} L M F \_P O S T C O N F 2_{t}+\beta_{5} A B S \Delta N I_{t}+\beta_{6} S I Z E_{t-1}+\beta_{7} L E V L O N G_{t-1}+\beta_{8} I N V R E C_{t-1}+ \\
& \beta_{9} \text { GROWTH }_{t}+\beta_{10} \text { ROA }_{t-1}+\beta_{11} \text { ETR }_{t}+\beta_{12} \text { REVTA }_{t}+\beta_{13} \text { ABMAT }_{t}+\beta_{14} \text { LOSS }_{t}+ \\
& \beta_{15} \text { SUSPECT }_{t}+\sum \emptyset_{i} I_{N D S E C}+\sum \alpha_{i} Y E A R_{i}+\varepsilon_{t}
\end{aligned}
$$

The variables, whose firm subscript is suppressed for simplicity, are defined in the Appendix.

\section{Results}

\subsection{Descriptive statistics and univariate analysis}

Table 3 presents descriptive statistics for each variable considered in the base regression model and related comparisons of pre-, confiscation and post-confiscation LMF-years with LWFyears. The authors report medians because they are less likely than means to be influenced by extreme observations. All continuous variables are winsorized at the top and bottom 1 percent of their distributions to avoid the influence of outliers.

\section{(Insert Table 3 approximately here)}

As regards dependent variables, medians of variables $A B S D A C, A B S D R E V$ and $A B S D E X P$ are all significantly $(\mathrm{p}<0.01)$ higher for pre-confiscation LMFs $(\mathrm{LMF}$ _PRECONF) relative to LWFs, providing a first indication in support of the hypotheses $\mathrm{H} 2 \mathrm{a}, \mathrm{H} 3 \mathrm{a}$ and $\mathrm{H} 4 \mathrm{a}$, respectively. Conversely, median of variable SMTH is higher for LMF_PRECONF but not significantly at conventional levels, providing some uncertainty on the support for hypothesis H1a. On the other hand, in the confiscation year (LMF_CONF) variables ABSDAC, ABSDREV and ABSDEXP are significantly $(\mathrm{p}<0.05, \mathrm{p}<0.01, \mathrm{p}<0.01$, respectively) higher for LMFs and variable SMTH is not significantly different, consistent with hypotheses $\mathrm{H} 1 \mathrm{~b}, \mathrm{H} 2 \mathrm{~b}, \mathrm{H} 3 \mathrm{~b}$ and $\mathrm{H} 4 \mathrm{~b}$. In addition, there is no significant difference in level of SMTH, ABSDAC and ABSDREV between LWFs and LMFs in the first post-confiscation year (LMF_POSTCONF1), whereas in the following postconfiscation years (LMF_POSTCONF2) ABSDAC and SMTH are even significantly (p<0.01) lower. Finally, variable ABSDEXP is still significantly $(\mathrm{p}<0.05)$ higher for LMFs in the first post-confiscation year and it only becomes insignificantly different in the following post- 
confiscation years. Overall, these results provide a first support for hypotheses H1c, H2c, H3c and $\mathrm{H} 4 \mathrm{c}$.

As regards the signed values of the accrual management proxies, there is no significant difference in level of $D A C$ between LWFs and pre-confiscation LMFs, indicating a null directional effect on income of accrual management practices within LMFs. In contrast, variable $D A C$ is negative and significantly $(\mathrm{p}<0.01)$ lower for LMFs in the confiscation year. On the other hand, variables $D R E V$ and $D E X P$ are both positive and significantly higher, at different conventional levels, for LMFs both before confiscation and in the confiscation year. This suggests that LMFs may simultaneously engage in income-increasing revenue accrual management and income-decreasing expense accrual management, whose effects on income are only significant in the year of confiscation as reflected by the DAC aggregate accrual management proxy. Overall, these results provide a first confirmation of Stubben's (2010) findings on the superiority of specific accrual models over aggregate accrual models in detecting a combination of revenue and expense manipulation especially in growth firms such as LMFs.

Turning to control variables, it is noteworthy that in the years following the confiscation LMFs appear significantly $(\mathrm{p}<0.01)$ more long term indebted $(L E V L O N G)$ than LWFs. This may be due to the loss of the criminal organization support granting financial resources and competitive advantages (Arlacchi, 1983; Fantò, 1999). In addition, both before and after confiscation LMFs are significantly $(\mathrm{p}<0.01)$ less profitable $(R O A)$ than LWFs. An overinvestment of financial resources stemming from illegal activities and a downward real earnings management may explain the lower profitability of LMFs before confiscation. On the other hand, the cost of the reinstatement of legality and the loss of business opportunities and competitive advantages (Arlacchi, 1983; Fantò, 1999) may be the causes after confiscation. A further consistent indication is the significantly $(\mathrm{p}<0.01)$ higher total assets growth rate (GROWTH) of LMFs before confiscation, presumably financed with dirty money, that becomes significantly $(\mathrm{p}<0.01)$ lower after confiscation because of the likely suspension of any money laundering activity. As regards real earnings management variable $A B M A T$, it is significantly $(\mathrm{p}<0.01)$ higher for LMFs both before and after confiscation, whereas abnormal revenues $($ REVTA $)$ are significantly $(\mathrm{p}<0.01)$ lower both before and after confiscation.

Table 4 shows that Pearson correlations among independent variables of the base regression model in Eq. (6) are low (below 0.29), thus providing a first indication that collinearity is unlikely to affect estimations.

\section{(Insert Table 4 approximately here)}




\subsection{Multivariate regression analysis}

In order to test the hypotheses, the authors estimate the model in Eq. (7) through a linear regression with standard errors adjusted by a two dimensional cluster at the firm and year levels (Gow et al., 2010; Colin et al., 2011), considering the likely correlation of the residuals across firm and/or over time. Table 5 presents the results for the unsigned accrual management proxies.

\section{(Insert Table 5 approximately here)}

First of all, it is noteworthy that all the estimated regressions are significant at the 0.01 level according to the chi-square tests. As regards variables relevant for the hypotheses, coefficient on $L M F \_P R E C O N F$ is positive and significant at conventional levels in all regressions. These results provide support for hypotheses $\mathrm{H} 1 \mathrm{a}, \mathrm{H} 2 \mathrm{a}, \mathrm{H} 3 \mathrm{a}$ and $\mathrm{H} 4 \mathrm{a}$, indicating that LMFs before confiscation engage more in earnings smoothing as well as in aggregate, revenue and expense accrual management, respectively. Interestingly, coefficient on $L M F \_C O N F$ is also positive and significant $(\mathrm{p}<0.01)$ in all regressions except in $S M T H$ regression, where it is not significant at conventional levels, consistent with hypotheses $\mathrm{H} 1 \mathrm{~b}, \mathrm{H} 2 \mathrm{~b}, \mathrm{H} 3 \mathrm{~b}$ and H4b. Hence, in the confiscation year LMFs continue engaging more in accrual management than LWFs do, although for reasons other than smoothing earnings. On the other hand, coefficient on $L M F \_P O S T C O N F 1$ is not significant at conventional levels in SMTH, ABSDAC and ABSDREV regressions, whereas it is still positive and significant $(\mathrm{p}<0.01)$ in $A B S D E X P$ regression. Finally, coefficient on $L M F \_P O S T C O N F 2$ is not significant at conventional levels in SMTH, $A B S D A C$ and $A B S D E X P$ regressions, whereas it is only marginally significant $(\mathrm{p}<0.10)$ in $A B S D R E V$ regression. Overall, these latter results provide support for hypotheses $\mathrm{H} 1 \mathrm{c}, \mathrm{H} 2 \mathrm{c}$, $\mathrm{H} 3 \mathrm{c}$ and $\mathrm{H} 4 \mathrm{c}$ indicating that, after the accounting adjustments carried out by legal administrators in the year of confiscation, in the post-confiscation years accrual management in LMFs tends to become consistent with that of LWFs.

As regards the rest of control variables, it is noteworthy that all their coefficients are mostly significant at the 0.01 level and with the expected sign, based on previous studies, with only some few exceptions. In particular, coefficient on $G R O W T H$ is positive and significant $(\mathrm{p}<0.01)$ in all regressions indicating that accrual management is more intensive in faster growing firms. On the other hand, coefficients on SIZE, LEVLONG, ROA and ETR are negative and significant at conventional levels, suggesting that larger, more long-term indebted, more profitable and less tax avoider firms engage less in accrual management, respectively. Furthermore, coefficients on $R E V T A$ is positive and significant $(\mathrm{p}<0.01)$ in all regressions providing evidence that firms showing higher abnormal revenues engage more in accrual management. Finally, coefficient 
on $A B M A T$ is positive and significant $(\mathrm{p}<0.01)$ in $S M T H, A B S D A C$ and $A B S D E X P$ regressions, whereas it is not significant in $A B S D R E V$ regression, suggesting that real earnings management through abnormal material expenses is mostly reflected in expense accrual management rather than revenue accrual management.

In summary, the multiple regression analysis suggests that before confiscation and in the year of confiscation LMFs engage more in aggregate, revenue and expense accrual management than LWFs do. In contrast, in the rest of post-confiscation years, after the initial accounting adjustments and regularizations performed by legal administrators, LMFs tend to adopt accrual management practices more similar to those of LWFs.

\subsection{Additional analysis}

\subsubsection{Matching procedure}

The authors perform a robustness test of the results by estimating the base regression model within a matched sample. So as to define a control sample, researchers choose from a wide range of firm characteristics on which to match such as: cash flows, year, industry, net income, size proxied by sales or total assets, ROA, etc. (Defond and Jiambalvo, 1994; Perry and Williams, 1994; Defond and Subramanyam, 1998; Teoh et al., 1998; Kothari et al., 2005). The authors match each LMF-year to three LWF-years on year, industry, sign of ROA and size proxied by total assets. Table 6 shows the results of the estimations with standard errors adjusted by a two dimensional cluster at the firm and year levels.

\section{(Insert Table 6 approximately here)}

All the estimated regressions are significant at the 0.01 level according to the chi-square tests. Results of matched sample estimations are mostly consistent with those of the unmatched sample. Indeed, coefficients on variables $L M F \_P R E C O N F$ and $L M F \_C O N F$ are positive and significant at conventional levels in all regressions. However, in SMTH regression coefficient on $L M F \_C O N F$ is only marginally significant $(\mathrm{p}<0.10)$, consistent with the hypothesized weakening of the incentive to smooth earnings. On the other hand, coefficients on variables LMF_POSTCONF1 and LMF_POSTCONF2 are not significant at conventional levels with the exceptions of marginally significant $(\mathrm{p}<0.10)$ coefficients on $L M F \_P O S T C O N F 1$ in ABSDEXP regression and on $L M F \_P O S T C O N F 2$ in ABSDREV regression. Overall, these results provide further support for all the hypotheses. As regards the rest of control variables, signs of coefficients are mostly consistent with those of the unmatched sample estimations, although some coefficients are not significant at conventional levels. 
In summary, the documented robustness of the results to different estimation methods can relieve concerns that the findings are driven by uncontrolled factors.

\subsubsection{Regression analysis with signed accrual management proxies}

To test the hypotheses, similar to previous studies (Warfield et al., 1995; Klein, 2002; Kim et $a l ., 2012)$, this study uses the unsigned value of the discretionary accruals proxies given that accrual management can be either income-increasing or income-decreasing. However, to address the possibility that the difference in accrual management between LMFs and LWFs is also directional in terms of impact on the income, the authors re-estimate the base regression model in Eq. (7) using the signed measures of accrual management. Table 7 shows the results of the estimations with standard errors adjusted by a two dimensional cluster at the firm and year levels.

\section{(Insert Table 7 approximately here)}

Again, all the estimated regressions are significant at the 0.01 level according to the chi-square tests. Interestingly, coefficient on variable $L M F_{-} P R E C O N F$ is not significant at conventional levels in any regression. These results are plausible given that in the long-term accrual management can hardly be directional. Indeed, discretionary accruals in one period must reverse in another period (Dechow et al., 2012). Furthermore, earnings smoothing and money laundering concealing may require both positive and negative discretionary accruals.

On the other hand, coefficient on $L M F_{-} C O N F$ is positive and significant $(\mathrm{p}<0.01)$ in both $D R E V$ and $D E X P$ regression, whereas it is negative and significant $(\mathrm{p}<0.05)$ in $D A C$ regression. Overall, these results suggest that in the confiscation year LMFs upward manage both revenue and expense accruals with a negative cumulative effect on aggregate accruals and income. Adjustments of prior to confiscation misreporting and the regularization of some transactions carried out by legal administrators may explain these results. Furthermore, there may be uncollectible receivables and outstanding payables, whose settlement is frozen by legal administrators, given that they may be related to fictitious transactions with colluded parties under investigation.

More importantly, these results represent a further confirmation of Stubben's (2010) findings on the informative superiority of specific accrual models over aggregate accrual models in detecting a combination of revenue and expense manipulation. Finally, we find similar results by repeating the estimations within a matched sample. 


\subsubsection{Alternative measure of discretionary accruals}

In order to test the robustness of the results to alternative measures of accrual management, we repeat the estimations of our model of Eq. (7) by using discretionary working capital accruals based on the Dechow and Dichev's (2002) model, which previous studies (Jones et al., 2008) find to be highly associated with the existence of fraudulent accounting manipulations. In particular, discretionary working capital accruals $\left(A B S D A C \_D D\right)$ are computed as the absolute value of residuals from the following Eq. (8), estimated in the same way as Eq. (1):

$$
\frac{\Delta W C_{t}}{T A_{t-1}}=\beta_{0}+\beta_{1} \frac{C F O_{t-1}}{T A_{t-1}}++\beta_{2} \frac{C F O_{t}}{T A_{t-1}}+\beta_{3} \frac{C F O_{t+1}}{T A_{t-1}}+\varepsilon_{t}
$$

Where $\Delta W C$ is the change in working capital from year $t-1$ to year $t$ and it is equal to accrual variable ACCR of Eq. (2) excluding depreciation and amortization expenses.

Table 8 shows the results of the estimations with standard errors adjusted by a two dimensional cluster at the firm and year levels.

\section{(Insert Table 8 approximately here)}

The estimated ABSDAC_DD regression is significant at the 0.01 level according to the chisquare test. Interestingly, coefficient on variable $L M F \_P R E C O N F$ is positive and significant $(\mathrm{p}<0.01)$, consistent with the hypothesis on the more intensive accrual management of LMFs before confiscation. Conversely, coefficients on variables $L M F \_C O N F, L M F \_P O S T C O N F 1$ and $L M F \_P O S T C O N F 2$ are not significant at conventional levels, suggesting that in the confiscation and post-confiscation years there is no significant difference in working capital accrual management between LMFs and LWFs. This provides further evidence of the significant impact of the intervention of legal administrators on LMFs practices.

It is noteworthy that, unlike $A B S D A C \_D D$ regression, coefficient on variable $L M F \_C O N F$ is significant $(\mathrm{p}<0.01)$ in the previously examined $A B S D A C$ regression, consistent with hypothesis $\mathrm{H} 2 \mathrm{~b}$ of this study. This difference between the two regressions may be due to the fact that working capital accruals of Dechow and Dichev's model do not include long-term accruals such as depreciation and amortization expenses. This is a further confirmation of the need to examine specific accruals rather than aggregate accruals in order to gain a deeper insight into how accrual management is actually performed.

\section{Discussions and conclusions}

In this study the authors examine how accounting is used to disguise and realize Mafia money laundering activities and whether discretionary expense, revenue and aggregate accruals can provide evidence of these illicit practices within a sample of 224 Italian firms, defined as LMFs, 
due to having been confiscated by judicial authorities because of their owners being accused of Mafia-type association.

Overall, the results reveal that in the pre- and confiscation years LMFs manage aggregate, revenue and expense accruals in order to smooth earnings and disguise money laundering. In contrast, in the post-confiscation years there is no significant difference in level of accrual management between LMFs and LWFs because of the intervention of legal administrators. Furthermore, in the confiscation year LMFs upward manage both revenue and expense accruals with a negative cumulative effect on aggregate accruals and income.

Importantly, the results confirm previous studies on unlisted firms finding that the use of financial statements in contracting with stakeholders may deter accrual management for illicit purposes such as tax avoidance (Klassen, 1997; Beatty and Harris, 1999; Coppens and Peek, 2005). Indeed, the more intensive accrual management within LMFs may be explained by their competitive advantages and market power, arising from the artificial scarcity they create (Champeyrache, 2014), that make their financial statements irrelevant to the determination of the terms of trades with stakeholders.

Previous studies find that several discretionary accrual proxies show significant differences, relative to a control sample, for firms charged by the U.S. Securities and Exchange Commission (SEC) with having committed fraud by overstating earnings (Dechow et al., 1995; Jones et al., 2008; Stubben, 2010; Dechow et al., 2011). It is worth noting that these studies mostly employ discretionary aggregate accruals and focus on specifically detected fraudulent manipulations aiming to overstate earnings under specific stimuli and circumstances at certain points in time. On the other hand, this paper examines LMFs over several years, assuming accrual management to smooth earnings and disguise money laundering, rather than overstating earnings, to be systematically carried out for the whole period. Furthermore, the authors analyze both discretionary expense accruals and discretionary revenue accruals in order to provide better evidence of the scope of the manipulations. Hence, as a further contribution, this study shows that accrual models may provide evidence of fraudulent manipulations related to tax avoidance and money laundering as well as to overstatements of earnings.

In addition, this study relieves prior concerns on the ability of discretionary accrual proxies to detect fraudulent accounting manipulations (e.g. Dechow and Skinner, 2000; Jones et al., 2008; Stubben, 2010). Indeed, the detected change of the accrual management pattern, following the reinstatement of legality pursued by legal administrators after confiscation, suggests the effectiveness of discretionary accrual proxies in providing evidence of fraudulent accounting prior to confiscation. Therefore, discretionary aggregate and specific accrual 
measures can at least be considered as red flags which could complement other risk indicators of illicit practices in specific socio-economic and political contexts. More specifically, discretionary accrual values may be added to the criteria used by authorities to select firms to be regularly inspected in order to unmask money laundering and tax avoidance practices. Enhancing the efficiency and effectiveness of inspections would strengthen the fight against criminal funding. Furthermore, it would allow authorities to collect additional resources, through confiscation of criminally derived assets, and finance public policies in economically depressed regions, where criminal organizations find fertile ground. In this regard, Barone and Narciso (2015) document Mafia's ability to divert a substantial amount of public funds assigned to poor areas. Moreover, the detection and regularization of LMFs may restore free competition in the regions where they operate (Arlacchi, 1983; Fantò, 1999) and increase foreign direct investments (Daniele and Marani, 2011), with consequent benefits for the local economy.

However, these findings are subject to several limitations. Firstly, it cannot be rejected the possibility of a bias in the selection of the sample of LMFs, considering that undetected LMFs are unobservable and smaller LMFs, unavailable on AIDA, are excluded. Furthermore, there could be selection biases in LMFs pursued and confiscated by Italian judicial authorities. Finally, the measures of accrual management in LMFs greatly depend on the reliability of reported financial statement figures. Indeed, the likely manipulation of these figures and the consequent endogenity in the calculation models may affect the correct interpretation of the measures. However, the consistent results of the estimations within a matched sample may partially relieve this concern.

The authors envisage some opportunities for future research. First, this study could be replicated in other countries, where money laundering is widespread, in order to determine whether its results are confirmed in a different cultural, legal and institutional context. In particular, previous studies (Forgione, 2009; Roth, 2009; Transcrime, 2013) document the infiltration of Italian Mafia in the legal economy of several European countries (e.g. Spain, Germany, Netherlands) and the aforementioned Eurostat (2013) study on money laundering finds that money laundering practices involving firms are widespread across all European countries. Second, additional accrual management proxies and models could be developed and tested in order to consider further specific accruals which may be linked to money laundering activities or other illicit practices. Finally, accrual management proxies jointly with other financial and non-financial variables could be included in a logistic model which may contribute to the detection of firms engaging in money laundering activities. In particular, a 
logistic model would allow considering the predictive power of several additional variables and their association with the aforementioned illicit practices.

\section{Appendix}

\subsection{Definition of variables of the base regression model (Eq. (7))}

$A M \_P R O X Y$ (accrual management proxy) $=S M T H, D A C, A B S D A C, D R E V, A B S D R E V, D E X P$, ABSDEXP, ABSDAC_DD:

$S M T H=$ earnings smoothing measure as defined in Eq. (5)

$D A C=$ aggregate discretionary accruals equal to residuals from Eq. (1)

$A B S D A C=$ absolute value of $D A C$

$D R E V=$ discretionary revenue accruals equal to residuals from Eq. (3)

$A B S D R E V=$ absolute values of $D R E V$

$D E X P=$ discretionary expense accruals equal to residuals from Eq. (4)

$A B S D E X P=$ absolute value of $D E X P$

$A B S D A C \_D D=$ discretionary working capital accruals equal to absolute value of residuals from Eq. (8)

$L M F \_P R E C O N F=$ dummy variable taking value of 1 for pre-confiscation LMF-years and 0 otherwise

$L M F \_C O N F=$ dummy variable taking value of 1 for LMF-years in the confiscation year and 0 otherwise

$L M F \_P O S T C O N F 1=$ dummy variable taking value of 1 for LMF-years in the first year after confiscation year and 0 otherwise

LMF_POSTCONF2 = dummy variable taking value of 1 for all LMF-years following the first post-confiscation LMF-years and 0 otherwise

$A B S \triangle N I=$ absolute value of (net income - lagged net income)/ lagged total assets

$S I Z E=$ natural logarithm of total assets

$L E V L O N G=$ long-term liabilities divided by total assets

$I N V R E C=$ total inventories and receivables divided by total assets

GROWTH $=($ total assets - lagged total assets $) /$ lagged total assets

$R O A=$ income before tax divided by total assets

$E T R=$ current tax expense divided by income before tax

REVTA $=$ total revenues divided by total assets standardized by industry and year $A B M A T=$ abnormal material expenses equal to residuals from Eq. (6) 
LOSS = dummy variable that that takes a value of 1 if the firm had two or more consecutive years of negative income including the current and 0 otherwise

SUSPECT = dummy variable that takes a value of 1 for firm-years with earnings before tax over lagged assets greater than or equal to zero but less than 0.01 and 0 otherwise $I N D S E C=$ dummy variables representing industry defined by the two-digit SIC code $Y E A R=$ dummy variables representing the fiscal year

\subsection{Abbreviations}

ANBSC National agency for the management and assignment of seized and confiscated assets

CFO Cash flow from operations

DAC Discretionary aggregate accruals

DEXP Discretionary expense accruals

DREV Discretionary revenue accruals

GAAP Generally accepted accounting principles

IFRS International financial reporting standard

LMFs Legally registered Mafia firms

LWFs Lawful firms

SEC Securities and Exchange Commission

SIC Standard industrial classification

\section{References}

Alford, A., Jones, J., Leftwich, R. and Zmijewski, M. (1993), “The relative informativeness of accounting disclosures in different countries", Journal of Accounting Research, Vol. 31 Supplement, pp. 183-223.

Alissa, W., Bonsall, S.B., Koharki, K. and Penn, M.W. (2013), "Firms' use of accounting discretion to influence their credit ratings", Journal of Accounting and Economics, Vol. 55 Nos 2-3, pp. 129-147.

ANBSC (2012), "Relazione annuale dell'Agenzia Nazionale per l'amministrazione e la destinazione dei beni sequestrati e confiscati alla criminalità organizzata", available at: http://www.benisequestraticonfiscati.it/Joomla/images/pdf/relazioni/2012_relazione_annuale anbsc.pdf (accessed 02 December 2015). 
Anselmo, M. (2009), "L'impero del calcestruzzo in terra di lavoro: le trame dell'economia criminale del clan dei casalesi”, in Gribaudi, G. (Ed.), Traffici criminali. Camorra, mafie e reti internazionali dell'illegalità, Bollati Boringhieri, Torino, pp. 505-537.

Arlacchi, P. (1983), La mafia imprenditrice: L'etica mafiosa e lo spirito del capitalismo, Il Mulino, Bologna.

Arlacchi, P. (2007), La mafia imprenditrice. Dalla Calabria al centro dell'inferno, Il Saggiatore, Milano.

Arya, A., Glover, J. and Sunder, S. (1998), "Earnings management and the revelation principle”, Review of Accounting Studies, Vol. 3 Nos 1-2, pp. 7-34.

Arya, A., Glover, J. and Sunder, S. (2003), "Are unmanaged earnings always better for shareholders?”, Accounting Horizons, Vol. 17 Suppl., pp. 111-116.

Badertscher, B.A. (2011), "Overvaluation and the choice of alternative earnings management mechanisms", Accounting Review, Vol. 86 No. 5, pp. 1491-1518.

Ball, R., Kothari, S.P. and Robin, A. (2000), "The effect of international institutional factors on properties of accounting earnings", Journal of Accounting and Economics, Vol. 29 No. 1, pp. $1-51$.

Ball, R. and Shivakumar, L. (2005), "Earnings quality in UK private firms: Comparative loss recognition timeliness", Journal of Accounting and Economics, Vol. 39 No. 1, pp. 83-128.

Barone, G. and Narciso, G. (2015), "Organized crime and business subsidies: Where does the money go?", Journal of Urban Economics, Vol. 86, pp. 98-110.

Beatty, A. and Harris, D.G. (1999), "The effects of taxes, agency costs and information asymmetry on earnings management: A comparison of public and private firms", Review of Accounting Studies, Vol. 4 Nos 3-4, pp. 299-326.

Beneish, M.D. (1997), "Detecting GAAP violation: Implications for assessing earnings management among firms with extreme financial performance", Journal of Accounting and Public Policy, Vol. 16 No. 3, pp. 271-309.

Bergstresser, D. and Philippon, T. (2006), "CEO incentives and earnings management", Journal of Financial Economics, Vol. 80 No. 3, pp. 511-529.

Bernard, V.L. and Skinner, D.J. (1996), "What motivates managers' choice of discretionary accruals?", Journal of Accounting and Economics, Vol. 22 Nos 1-3, pp. 313-325.

Bromley, P. and Powell, W.W. (2012), "From smoke and mirrors to walking the talk: Decoupling in the contemporary world", Academy of Management Annals, Vol. 6 No. 1, pp. $483-530$. 
Buchanan, B. (2004), "Money laundering - a global obstacle", Research in International Business and Finance, Vol. 18 No. 1, pp. 115-27.

Buonanno, P., Prarolo, G. and Vanin, P. (2016), “Organized crime and electoral outcomes. Evidence from Sicily at the turn of the XXI century", European Journal of Political Economy, Vol. 41, pp. 61-74.

Burgstahler, D.C., Hail, L. and Leuz, C. (2006), “The importance of reporting incentives: Earnings management in European private and public firms", Accounting Review, Vol. 81 No. 5, pp. 983-1016.

Calderoni, F. and Riccardi, M. (2011), "The investments of organized crime in Italy: An exploratory analysis", paper presented at the 63rd American Society of Criminology, Washington DC.

Caneppele, S., Calderoni, F. and Martocchia, S. (2009), "Not only banks: Criminological models on the infiltration of public contracts by Italian organized crime", Journal of Money Laundering Control, Vol. 12 No. 2, pp. 151 - 172.

Capacchione, R. (2008), L'oro della camorra, Rizzoli, Milano.

Capalbo, F., Frino, A., Mollica, V. and Palumbo, R. (2014), “Accrual-based earnings management in state owned companies: Implications for transnational accounting regulation", Accounting, Auditing \& Accountability Journal, Vol. 27 No. 6, pp. 1026 - 1040.

Catanzaro, R. (1985), "Enforcers, entrepreneurs, and survivors: How the Mafia has adapted to change”, British Journal of Sociology, Vol. 36 No. 1, pp. 34-57.

Caylor, M.L. (2010), "Strategic revenue recognition to achieve earnings benchmarks", Journal of Accounting and Public Policy, Vol. 29 No. 1, pp. 82-95.

Champeyrache, C. (2004), Entreprise Légale, Propriétaire Mafieux: Comment la Mafia Infiltre l'Economie Légale, Editions CNRS, Paris.

Champeyrache, C. (2014), "Artificial Scarcity, Power, and the Italian Mafia”, Journal of Economic Issues, Vol. 48 No. 3, pp. 625-639.

Chaney, P.K., Faccio, M. and Parsley, D. (2011), "The quality of accounting information in politically connected firms", Journal of Accounting and Economics, Vol. 51 Nos 1-2, pp. 5876.

Charitou, A., Lambertides, N. and Trigeorgis, L. (2007), "Managerial discretion in distressed firms", British Accounting Review, Vol. 39 No. 4, pp. 323-346.

Chih, H., Shen, C. and Kang, F. (2008), “Corporate social responsibility, investor protection, and earnings management: Some international evidence”, Journal of Business Ethics, Vol. 79 Nos 1-2, pp. 179-198. 
Cohen, D.A., Dey, A. and Lys, T.Z. (2008), "Real and accrual-based earnings management in the pre- and post-sarbanes-oxley periods", Accounting Review, Vol. 83 No. 3, pp. 757-787.

Cohen, D.A. and Zarowin, P. (2010), “Accrual-based and real earnings management activities around seasoned equity offerings", Journal of Accounting and Economics, Vol. 50 No. 1, pp. $2-19$.

Cohen, J., Ding, Y., Lesage, C. and Stolowy, H. (2010), "Corporate fraud and managers' behavior: Evidence from the press", Journal of Business Ethics, Vol. 95 No. 2, pp. 271-315.

Colin, A.C., Gelbach, J.B. and Miller, D.L. (2011), "Robust Inference with Multiway Clustering”, Journal of Business and Economic Statistics, Vol. 29 No. 2, pp. 238-249. Compin, F. (2008), "The role of accounting in money laundering and money dirtying", Critical Perspectives on Accounting, Vol. 19 No. 5, pp. 591-602.

Cooper, D.J., Dacin, T. and Palmer, D. (2013), "Fraud in accounting, organizations and society: Extending the boundaries of research", Accounting, Organizations and Society, Vol. 38 Nos 67, pp. 440-457.

Coppens, L. and Peek, E. (2005), "An analysis of earnings management by European private firms", Journal of International Accounting, Auditing and Taxation, Vol. 14 No. 1, pp. 1-17.

Cram, D.P., Karan, V. and Stuart, I. (2009), "Three Threats to Validity of Choice-based and Matched-Sample Studies in Accounting Research", Contemporary Accounting Research, Vol. 26 No. 2, pp. 477-516.

Daniele, V. and Marani, U. (2008), Organized crime and foreign direct investments: The Italian case, CESifo Group Munich, Munich.

Daniele, V. and Marani, U. (2011), "Organized crime, the quality of local institutions and FDI in Italy: a panel data analysis", European Journal of Political Economy, Vol. 27 No. 1, pp. 132142.

Dechow, P. and Dichev, I. (2002), “The quality of accruals and earnings: the role of accrual estimation errors", The Accounting Review, Vol. 77 No. 1, pp. 35-59.

Dechow, P.M., Ge, W., Larson, C.R. and Sloan, R.G. (2011), "Predicting material accounting misstatements", Contemporary Accounting Research, Vo. 28 No. 1, pp. 17-82.

Dechow, P.M., Hutton, A.P., Kim, J.H. and Sloan, R.G. (2012), "Detecting Earnings Management: A New Approach", Journal of Accounting Research, Vol. 50 No. 2, pp. 275-334. Dechow, P.M. and Skinner, D.J. (2000), "Earnings Management: Reconciling the Views of Accounting Academics, Practitioners, and Regulators", Accounting Horizons, Vol. 14 No. 2, pp. 235-250. 
Dechow, P.M., Sloan, R.G. and Sweeney, A.P. (1995), “Detecting Earnings Management”, The Accounting Review, Vol. 70 No. 2, pp. 193-226.

DeFond, M.L. and Jiambalvo, J. (1994), "Debt covenant violation and manipulation of accruals", Journal of Accounting and Economics, Vol. 17 Nos 1-2, pp. 145-176.

DeFond, M.L. and Subramanyam, K.R. (1998), “Auditor changes and discretionary accruals", Journal of Accounting and Economics, Vol. 25 No. 1, pp. 35-67.

Della Porta, D. and Vannucci, A. (2011), The governance of corruption, Ashgate, London.

Dichev, D., Graham, J.R., Harvey, C.R. and Rajgopal, S. (2013), "Earnings quality: Evidence from the field", Journal of Accounting and Economics, Vol. 56 Nos 2-3, pp. 1-33.

Dickie, J. (2004), Cosa Nostra: A history of the Sicilian mafia, Hodder \& Stoughton, London.

Di Fiore, G. (2008), L’impero dei casalesi, Rizzoli, Milano.

Duellman, S., Ahmed, A.S. and Abdel-Meguid, A.M. (2013), “An empirical analysis of the effects of monitoring intensity on the relation between equity incentives and earnings management", Journal of Accounting and Public Policy, Vol. 32 No. 6, pp. 495-517.

Dugger, W. (1980), "Power: An Institutional Framework of Analysis", Journal of Economic Issues, Vol. 14 No. 4, pp. 897-907.

Dugger, W. (1989), "Instituted Process and Enabling Myth: The Two Faces of the Market", Journal of Economic Issues, Vol. 23 No. 2, pp. 607-615.

Duplat, V., Very, P. and Monnet, B. (2012), "Identification and economic analysis of governance mechanisms in legally registered mafia firms", Management (France), Vol. 15 No. 3, pp. 273-282.

Eurostat (2013), "Money laundering in Europe - 2013 edition”, available at: http://ec.europa.eu/eurostat/web/products-statistical-working-papers/-/KS-TC-13-007 (accessed 28 February 2016).

Fanning, K.M. and Cogger, K.O. (1998), "Neural network detection of management fraud using published financial data", Intelligent Systems in Accounting, Finance and Management, Vol. 7 No. 1, pp. 21-41.

Fantò, E. (1999), L’impresa a partecipazione mafiosa. Economia Legale ed Economia Criminale, Delalo, Bari.

Financial Action Task Force (2006), “Typologies Report on Trade-based Money Laundering”, available at: http://www.fatf-gafi.org (accessed 02 December 2015).

Finckenauer, J.O. (2005), "Problems of definition: what is organized crime?", Trends in Organized Crime, Vol. 8 No. 3, pp. 63-83. 
Fiorentini, G. (1999), Organized crime and illegal markets, Università di Bologna, Dipartimento di Scienze Economiche, Bologna.

Forgione, F. (2009), Mafia export: Come 'ndrangheta, cosa nostra e camorra hanno colonizzato il mondo, Baldini Castoldi Dalai Editore, Milano.

Francis, J., LaFond, R., Olsson, P. and Schipper, K. (2005), “The market pricing of accruals quality”, Journal of Accounting and Economics, Vol. 39 No. 2, pp. 295-327.

Gabbioneta, C., Greenwood, R., Mazzola, P. and Minoja, M. (2013), "The influence of the institutional context on corporate illegality”, Accounting, Organizations and Society, Vol. 38 Nos 6-7, pp. 484-504.

Gambetta, D. (1993), The Sicilian Mafia: The business of private protection, MA: Harvard University Press, Cambridge.

Gambetta, D. and Reuter, P. (1995), “Conspiracy among the many: The mafia in legitimate industries", in Fiorentini, G. and Peltzman, S. (Ed.), The Economics of Organised Crime, University Press, Cambridge, pp. 116-136.

García Lara, J.M., García Osma, B. and Neophytou, E. (2009), "Earnings quality in ex-post failed firms", Accounting and Business Research, Vol. 39 No. 2, pp. 119-138.

Gargouri, R., Francoeur, C. and Shabou, R. (2010), “The relation between corporate social performance and earnings management", Canadian Journal of Administrative Sciences, Vol. 27 No. 4, pp. 320-334.

Ghosh, D. and Olsen, L. (2009), “Environmental uncertainty and managers' use of discretionary accruals", Accounting, Organizations and Society, Vol. 34 No. 2, pp. 188-205.

Gilmore, W.C. (1999), Dirty Money: The Evolution of Money Laundering Counter-Measures, Council of Europe Press, Strasbourg.

Gilmour, N. and Ridley, N. (2015), "Everyday vulnerabilities - money laundering through cash intensive businesses", Journal of Money Laundering Control, Vol. 18 No. 3, pp. 293 - 303.

Goncharov, I. and Zimmermann, J. (2006), "Earnings management when incentives compete: the role of tax accounting in Russia", Journal of International Accounting Research, Vol. 5 No. 1, pp. 41-65.

Gond, J., Palazzo, G. and Basu, K. (2009), "Reconsidering Instrumental Corporate Social Responsibility through the Mafia Metaphor”, Business Ethics Quarterly, Vol. 19 No. 1, pp. 5785.

Gow, I., Ormazabal, G. and Taylor, D. (2010), "Correcting for cross-sectional and time-series dependence in accounting research", The Accounting Review, Vol. 85 No. 2, pp. 483-512. 
Graham, J.R., Harvey, C.R. and Rajgopal, S. (2005), "The economic implications of corporate financial reporting”, Journal of Accounting and Economics, Vol. 40 Nos 1-3, pp. 3-73.

Gunny, K.A. (2010), "The relation between earnings management using real activities manipulation and future performance: Evidence from meeting earnings benchmarks", Contemporary Accounting Research, Vol. 27 No. 3, pp. 855-888.

Guthrie, J. and Parker, L.D. (2011),"Reflections and projections", Accounting, Auditing \& Accountability Journal, Vol. 25 No. 1, pp. 6- 26.

Hanlon, M. and Heitzman, S. (2010), "A review of tax research", Journal of Accounting and Economics, Vol. 50 Nos 2-3, pp. 127-178.

He, P. (2010), “A typological study on money laundering”, Journal of Money Laundering Control, Vol. 13 No. 1, pp. 15 - 32.

Herrmann, D. and Inoue, T. (1996), "Income smoothing and incentives by operating condition: an empirical test using depreciation changes in Japan", Journal of International Accounting Auditing and Taxation, Vol. 5 No. 2, pp. 161-177.

Hung, M. (2000), "Accounting standards and value relevance of financial statements: An international analysis", Journal of Accounting and Economics, Vol. 30 No. 3, pp. 401-420.

Ibrahim, S., Xu, L. and Rogers, G. (2011), "Real and accrual-based earnings management and its legal consequences: Evidence from seasoned equity offerings", Accounting Research Journal, Vol. 24 No. 1, pp. 50-78.

Jones, J. (1991), "Earnings management during import relief investigations", Journal of Accounting Research, Vol. 29 No. 2, pp. 193-228.

Jones, K.L., Krishnan, G.V. and Melendrez, K.D. (2008), "Do models of discretionary accruals detect actual cases of fraudulent and restated earnings? An empirical analysis", Contemporary Accounting Research, Vol.25 No. 2, pp. 499-531.

Kim, Y., Park, M.S. and Wier, B. (2012), "Is earnings quality associated with corporate social responsibility?”, Accounting Review, Vol. 87 No. 3, pp. 761-796.

Klassen, K.J. (1997), “The impact of inside ownership concentration on the trade-off between financial and tax reporting”, Accounting Review, Vol. 72 No. 3, pp. 455-474.

Klein, A. (2002), "Audit committee, board of director characteristics, and earnings management", Journal of Accounting and Economics, Vol. 33 No. 3, pp. 375-400.

Kothari, S.P., Leone, A.J. and Wasley, C.E. (2005), "Performance matched discretionary accrual measures", Journal of Accounting and Economics, Vol. 39 No. 1, pp. 163-197.

Lanis, R. and Richardson, G. (2012), "Corporate social responsibility and tax aggressiveness: An empirical analysis", Journal of Accounting and Public Policy, Vol. 31 No. 1, pp. 86-108. 
Lavezzi, A.M. (2008), "Economic structure and vulnerability to organised crime: Evidence from Sicily", Global Crime, Vol. 9 No. 3, pp. 198-220.

Lee, T.A., Ingram, R.W. and Howard, T.P. (1999), “The difference between earnings and operating cash flow as an indicator of financial reporting fraud", Contemporary Accounting Research, Vol. 16 No. 4, pp. 749-786.

Levi, M. and Reuter, P. (2006), "Money laundering”, Crime and Justice, Vol. 34 No. 1, pp. 289-376.

Lo Bello, I. (2011), "Mafia e mercato", in Danna, S. (Ed.), Prodotto interno mafia. Così la criminalità organizzata è diventata il sistema Italia, Einaudi, Torino, pp. 77-104.

Lukes, S. (2005), Power: A radical view, Palgrave Macmillan, London.

Maitland Irwin, A.S., Raymond Choo, K. and Liu, L. (2012), “An analysis of money laundering and terrorism financing typologies", Journal of Money Laundering Control, Vol. 15 No. 1, pp. $85-111$.

Marquardt, C.A. and Wiedman, C.I. (2004), "How are earnings managed? An examination of specific accruals", Contemporary Accounting Research, Vol. 21 No. 2, pp. 461-491.

Marques, M., Rodrigues, L.L. and Craig, R. (2011), "Earnings management induced by tax planning: the case of Portuguese private firms", Journal of International Accounting, Auditing and Taxation, Vol. 20 No. 2, pp. 83-96.

Martocchia, S., Tenti, V. and Calderoni, F. (2014), "Infiltrare gli appalti: i casi di studio", in Caneppele, S. (Ed.), Le mafie dentro gli appalti: Casi di studio e modelli preventivi, Franco Angeli, Milano, pp. 11-111.

Masciandaro, D. (1997), “Crisi d'impresa e criminalità”, in Masciandaro, D. and Riolo, F. (Ed.), Crisi d'impresa e risanamento, Edibank, Milano, pp. 73-114.

Mattina, C. (2011), "The transformations of the contemporary mafia: a perspective review of the literature on mafia phenomena in the context of the internationalisation of the capitalist economy”, International Social Science Journal, Vol. 62 Nos 203-204, pp. 229-245.

McKendall, M.A. and Wagner, J.A. (1997), "Motive, opportunity, choice, and corporate illegality", Organization Science, Vol. 8 No. 6, pp. 624-647.

McNichols, M. and Wilson, P. (2000), "Research design issues in earnings management studies”, Journal of Accounting and Public Policy, Vol. 19 Nos 4-5, pp. 313-345.

Misangyi, V.F., Weaver, G.R. and Elms, H. (2008), "Ending corruption: The interplay among institutional logics, resources, and institutional entrepreneurs", Academy of Management Review, Vol. 33 No. 3, pp. 750-770. 
Morales, J., Gendron, Y. and Guénin-Paracini, H. (2014), "The construction of the risky individual and vigilant organization: A genealogy of the fraud triangle", Accounting, Organizations and Society, Vol. 39 No. 3, pp. 170-194.

O'Dwyer, B. and Unerman, J. (2014), "Realizing the potential of interdisciplinarity in accounting research", Accounting, Auditing \& Accountability Journal, Vol. 27 No. 8, pp. 12271232.

Palmer, D. (2012), Normal Organizational Wrongdoing: A critical analysis of theories of misconduct in and by organizations, Oxford University Press, Oxford.

Parker, L.D. and Guthrie, J. (2014), "Addressing directions in interdisciplinary accounting research", Accounting, Auditing \& Accountability Journal, Vol. 27 No. 8, pp. 1218 - 1226.

Perols, J.L. and Lougee, B.A. (2011), “The relation between earnings management and financial statement fraud", Advances in Accounting, Vol. 27 No. 1, pp. 39-53.

Perry, S.E. and Williams, T.H. (1994), "Earnings management preceding management buyout offers", Journal of Accounting and Economics, Vol. 18 No. 2, pp. 157-179.

Prencipe, A., Markarian, G. and Pozza, L. (2008), "Earnings management in family firms: Evidence from RandD cost capitalization in Italy”, Family Business Review, Vol. 21 No. 1, pp. 71-88.

Riccardi, M. (2014), "When criminals invest in businesses: Are we looking in the right direction? An exploratory analysis of companies controlled by mafias", in Calderoni, F. and Caneppele, S. (Ed.), Organized crime, corruption and crime prevention. Essays in honor of Ernesto U. Savona, Springer, New York, pp. 197-206.

Rosner, R.L. (2003), "Earnings manipulation in failing firms", Contemporary Accounting Research, Vol. 20 No. 2, pp. 361-408.

Roth, J. (2009), Mafialand Deutschland, Wilhelm Heine, München.

Roychowdhury, S. (2006), "Earnings management through real activities manipulation", Journal of Accounting and Economics, Vol. 42 No. 3, pp. 335-370.

Savona, E.U. (2010), "Infiltration of the public construction industry by Italian organised crime”, in Bullock, K., Clarke, R.V. and Tilley, N. (Ed.), Situational Prevention of Organised Crimes, Willan Publishing, Portland, pp. 130-150.

Savona, E.U. (2015), “The Businesses of Italian Mafias”, European Journal on Criminal Policy and Research, Vol. 21 No. 2, pp. 217-236.

Savona, E.U. and Riccardi, M. (2015), From illegal markets to legitimate businesses: The portfolio of organised crime in Europe, Transcrime - Università degli Studi di Trento, Trento. Sciarrone, R. (1998), Mafie vecchie, mafie nuove. Radicamento ed espansione, Donzelli, Roma. 
Sciarrone, R. (2014), Mafie Del Nord. Strategie Criminali E Contesti Locali, Donzelli, Roma. Sciarrone, R. and Storti, L. (2014), "The territorial expansion of mafia-type organized crime. The case of the Italian mafia in Germany", Crime, Law and Social Change, Vol. 61 No. 1, pp. 37-60.

Smith, M., Kestel, J. and Robinson, P. (2001), "Economic recession, corporate distress and income increasing accounting policy choice", Accounting Forum, Vol. 25 No. 4, pp. 335-352. Soltani, B. (2014), "The anatomy of corporate fraud: A comparative analysis of high profile American and European corporate scandals", Journal of Business Ethics, Vol. 120 No. 2, pp. 251-274.

Stubben, S.R. (2010), "Discretionary revenues as a measure of earnings management", Accounting Review, Vol. 85 No. 2, pp. 695-717.

Subramanyam, K.R. (1996), "The pricing of discretionary accruals", Journal of Accounting and Economics, Vol. 22 No. 3, pp. 249-282.

Teoh, S.H., Welch, I. and Wong, T.J. (1998), "Earnings management and the long-run market performance of initial public offerings", Journal of Finance, Vol. 53 No. 6, pp. 1935-1974.

Transcrime (2013), "Progetto PON Sicurezza 2007-2013", available at: http://www.investimentioc.it/ (accessed 02 December 2015).

Van Tendeloo, B. and Vanstraelen, A. (2008), "Earnings management and audit quality in Europe: Evidence from the private client segment market", European Accounting Review, Vol. 17 No. 3, pp. 447-469.

Veblen, T. (1915), Theory of the Leisure Class: An Economic Study of Institutions, MacMillan, New York.

Veblen, T. (1921), The Engineers and the Price System, Harbinger, New York.

Venkatesh, S.A. (1997), "The social organization of street gang activity in an urban ghetto", American Journal of Sociology, Vol. 103 No. 1, pp. 82-111.

Walker, M. (2013), "How far can we trust earnings numbers? What research tells us about earnings management”, Accounting and Business Research, Vol. 43 No. 4, pp. 445-481.

Warfield, T.D., Wild, J.J. and Wild, K.L. (1995), "Managerial ownership, accounting choices, and informativeness of earnings", Journal of Accounting and Economics, Vol. 20 No. 1, pp. 61-92.

Westphal, J.D. and Clement, M.B. (2008), "Sociopolitical dynamics in relations between top managers and security analysts: Favour rendering, reciprocity, and analysts stock recommendations", Academy of Management Journal, Vol. 51 No. 5, pp. 873-897. 
Wilks, T.J. and Zimbelman, M.F. (2004), "Decomposition of fraud-risk assessments and auditors' sensitivity to fraud cues", Contemporary Accounting Research, Vol. 21 No. 3, pp. 719-745.

Wongsunwai, W. (2013), "The effect of external monitoring on accrual-based and real earnings management: Evidence from venture-backed initial public offerings", Contemporary Accounting Research, Vol. 30 No. 1, pp. 296-324.

Zang, A.Y. (2012), "Evidence on the trade-off between real activities manipulation and accrualbased earnings management", Accounting Review, Vol. 87 No. 2, pp. 675-703.

Zhao, Y., Chen, K.H., Zhang, Y. and Davis, M. (2012), “Takeover protection and managerial myopia: Evidence from real earnings management", Journal of Accounting and Public Policy, Vol. 31 No. 1, pp. 109-135. 
Table 1. Sample selection

Number of firms

LMFs sample

LMFs definitively confiscated at November 5th 2012 provided by 1,663

ANBSC

Less: LMFs provided by ANBSC with data unavailable on AIDA

database

Add: LMFs found on AIDA database with status confiscated

Add: confiscated LMFs found in online newspapers with data available in AIDA

Final LMFs sample

LMFs year observations in base regression model (ABSDAC)

\section{LWFs control sample}

Aida population of active and unlisted firms with available financial

data from 2003 to 2012 in the same two-digit SIC industries as LMFs

LWFs year observations in base regression model (ABSDAC)

540,339

Source: ANBSC and AIDA database, 2013. 
Table 2. Industry distribution of LMFs and AIDA population of active unlisted firms with available financial data from 2003 to 2012 restricted to LMFs industries

\begin{tabular}{|c|c|c|c|c|c|}
\hline \multirow[t]{2}{*}{ Sic code } & \multirow[t]{2}{*}{ Industry description } & \multicolumn{2}{|c|}{ AIDA population } & \multicolumn{2}{|c|}{ LMFs } \\
\hline & & Freq. & Percent & Freq. & Percent \\
\hline 01 & Agricultural production-crops & 644 & 0.82 & 4 & 1.79 \\
\hline 14 & $\begin{array}{l}\text { Mining and quarrying of } \\
\text { nonmetallic minerals, except fuels }\end{array}$ & 463 & 0.59 & 9 & 4.02 \\
\hline 15 & $\begin{array}{l}\text { Building construction-general } \\
\text { contractors and operative builders }\end{array}$ & 5,486 & 7.00 & 41 & 18.30 \\
\hline 16 & $\begin{array}{l}\text { Heavy construction other than } \\
\text { building construction-contractors }\end{array}$ & 524 & 0.67 & 3 & 1.34 \\
\hline 17 & $\begin{array}{l}\text { Construction-special trade } \\
\text { contractors }\end{array}$ & 4,032 & 5.15 & 8 & 3.57 \\
\hline 20 & Food and kindred products & 3,224 & 4.12 & 6 & 2.68 \\
\hline 25 & $\begin{array}{l}\text { Furniture and fixtures } \\
\text { manufacturing }\end{array}$ & 829 & 1.06 & 3 & 1.34 \\
\hline 28 & $\begin{array}{l}\text { Chemicals and allied products } \\
\text { manufacturing }\end{array}$ & 1,598 & 2.04 & 1 & 0.45 \\
\hline 29 & $\begin{array}{l}\text { Petroleum refining and related } \\
\text { industries }\end{array}$ & 158 & 0.20 & 2 & 0.89 \\
\hline 32 & $\begin{array}{l}\text { Stone, clay, glass and concrete } \\
\text { products manufacturing }\end{array}$ & 1,960 & 2.50 & 13 & 5.80 \\
\hline 34 & $\begin{array}{l}\text { Fabricated metal products, except } \\
\text { machinery and transportation } \\
\text { equipment }\end{array}$ & 7,038 & 8.98 & 2 & 0.89 \\
\hline 42 & $\begin{array}{l}\text { Motor freight transportation and } \\
\text { warehousing }\end{array}$ & 2,894 & 3.69 & 18 & 8.04 \\
\hline 44 & Water transportation & 586 & 0.75 & 1 & 0.45 \\
\hline 45 & Transportation by air & 95 & 0.12 & 1 & 0.45 \\
\hline 47 & Transportation services & 1,884 & 2.40 & 3 & 1.34 \\
\hline 49 & Electric, gas and sanitary services & 1,419 & 1.81 & 7 & 3.13 \\
\hline 50 & Wholesale trade, durable goods & 14,064 & 17.95 & 23 & 10.27 \\
\hline 51 & $\begin{array}{l}\text { Wholesale trade, nondurable goods } \\
\text { wholesale dealing in }\end{array}$ & 7,821 & 9.98 & 19 & 8.48 \\
\hline 52 & $\begin{array}{l}\text { Building materials, hardware, } \\
\text { garden supply, and mobile home } \\
\text { dealers wholesale dealing in }\end{array}$ & 1,018 & 1.30 & 1 & 0.45 \\
\hline 53 & General merchandise stores & 324 & 0.41 & 1 & 0.45 \\
\hline 54 & Food stores & 1,737 & 2.22 & 16 & 7.14 \\
\hline 55 & $\begin{array}{l}\text { Automotive dealers and gasoline } \\
\text { service stations }\end{array}$ & 536 & 0.68 & 4 & 1.79 \\
\hline 56 & Apparel and accessory stores & 1,920 & 2.45 & 3 & 1.34 \\
\hline 57 & $\begin{array}{l}\text { Home furniture, furnishings, and } \\
\text { equipment stores }\end{array}$ & 872 & 1.11 & 1 & 0.45 \\
\hline 58 & Eating and drinking places & 1,007 & 1.29 & 2 & 0.89 \\
\hline
\end{tabular}


Table 2. Industry distribution of LMFs and AIDA population of active unlisted firms with available financial data from 2003 to 2012 restricted to LMFs industries

\begin{tabular}{llcccc}
\hline Sic code & Industry description & AIDA population & \multicolumn{2}{c}{ LMFs } \\
& & Freq. & Percent & Freq. & Percent \\
\hline 59 & Miscellaneous retail & 1,475 & 1.88 & 1 & 0.45 \\
65 & Real estate & 2,239 & 2.86 & 7 & 3.13 \\
70 & Hotels, rooming houses, camps, and & 1,600 & 2.04 & 3 & 1.34 \\
& other lodging places & & & \\
72 & Personal services & 327 & 0.42 & 1 & 0.45 \\
73 & Business services & 5,001 & 6.38 & 2 & 0.89 \\
75 & Automotive repair, services, and & 882 & 1.13 & 1 & 0.45 \\
79 & parking & & & & \\
80 & Amusement and recreation services & 744 & 0.95 & 5 & 2.23 \\
81 & Health services & 1,165 & 1.49 & 9 & 4.02 \\
87 & Legal services & 19 & 0.02 & 1 & 0.45 \\
& Engineering, accounting, research, & 2,755 & 3.52 & 2 & 0.89 \\
\hline Total & management, and related services & & & & \\
\hline
\end{tabular}

Source: AIDA database, 2013. 
Table 3. Descriptive statistics and variable comparison between LMFs and LWFs Panel A. Descriptive statistics

\begin{tabular}{|c|c|c|c|c|c|c|c|c|c|c|}
\hline & \multicolumn{2}{|c|}{ LMF_PRECONF } & \multicolumn{2}{|c|}{ LMF_CONF } & \multicolumn{2}{|c|}{ LMF_POSTCONF1 } & \multicolumn{2}{|c|}{ LMF_POSTCONF2 } & \multicolumn{2}{|c|}{ LWFs } \\
\hline & $\mathbf{N}$ & Median & $\mathbf{N}$ & Median & $\mathbf{N}$ & Median & $\mathbf{N}$ & Median & $\mathbf{N}$ & Median \\
\hline \multicolumn{11}{|c|}{ Dependent Variables } \\
\hline SMTH & 562 & -0.3171 & 112 & -0.3312 & 88 & -0.3649 & 336 & -0.3968 & 550,835 & -0.3492 \\
\hline$D A C$ & 631 & -0.0004 & 98 & -0.0396 & 74 & -0.0002 & 291 & 0.0021 & 541,446 & -0.0006 \\
\hline$A B S D A C$ & 631 & 0.1197 & 98 & 0.0950 & 74 & 0.0694 & 291 & 0.0572 & 541,446 & 0.0780 \\
\hline$D R E V$ & 573 & 0.0110 & 90 & 0.0074 & 71 & -0.0098 & 277 & 0.0028 & 534,121 & -0.0085 \\
\hline$A B S D R E V$ & 573 & 0.0962 & 90 & 0.0954 & 71 & 0.0593 & 277 & 0.0516 & 534,121 & 0.0611 \\
\hline$D E X P$ & 585 & 0.0090 & 90 & 0.0343 & 71 & 0.0062 & 276 & 0.0071 & 549,070 & -0.0045 \\
\hline$A B S D E X P$ & 585 & 0.1061 & 90 & 0.1154 & 71 & 0.0952 & 276 & 0.0551 & 549,070 & 0.0662 \\
\hline \multicolumn{11}{|c|}{ Control Variables } \\
\hline$A B S \triangle N I$ & 750 & 0.0136 & 108 & 0.0347 & 87 & 0.0281 & 322 & 0.0176 & 671,114 & 0.0138 \\
\hline$S I Z E$ & 967 & 7.9444 & 115 & 8.1153 & 90 & 8.2226 & 348 & 8.2891 & 753,484 & 7.8023 \\
\hline$L E V L O N G$ & 967 & 0.0238 & 115 & 0.0353 & 90 & 0.0502 & 348 & 0.0781 & 753,480 & 0.0296 \\
\hline INVREC & 928 & 0.6439 & 109 & 0.6298 & 86 & 0.5912 & 334 & 0.5770 & 705,084 & 0.6141 \\
\hline GROWTH & 750 & 0.1089 & 108 & 0.0105 & 87 & 0.0147 & 322 & 0.0032 & 671,352 & 0.0371 \\
\hline$R O A$ & 967 & 0.0220 & 115 & 0.0130 & 90 & 0.0075 & 348 & 0.0113 & 753,371 & 0.0276 \\
\hline ETR & 966 & 0.4229 & 115 & 0.1828 & 90 & 0.3346 & 348 & 0.3503 & 751,630 & 0.5153 \\
\hline$R E V T A$ & 750 & -0.3405 & 108 & -0.4008 & 87 & -0.4430 & 322 & -0.4795 & 671,157 & -0.2087 \\
\hline$A B M A T$ & 622 & 0.0599 & 99 & 0.0463 & 82 & 0.0304 & 309 & 0.0701 & 661,717 & -0.0037 \\
\hline$\% L O S S$ & $3.90 \%$ & & $6.21 \%$ & & $19.01 \%$ & & $17.11 \%$ & & $6.34 \%$ & \\
\hline$\% S U S P E C T$ & $6.75 \%$ & & $5.65 \%$ & & $6.34 \%$ & & $6.60 \%$ & & $10.32 \%$ & \\
\hline
\end{tabular}


Table 3. Descriptive statistics and variable comparison between LMFs and LWFs Panel B. Variable median comparison between LMFs and LWFs

\begin{tabular}{|c|c|c|c|c|c|c|c|c|}
\hline & \multicolumn{2}{|c|}{$\begin{array}{c}\text { LMF_PRECONF } \\
\text { minus LWFs }\end{array}$} & \multicolumn{2}{|c|}{$\begin{array}{l}\text { LMF_CONF } \\
\text { minus LWFs }\end{array}$} & \multicolumn{2}{|c|}{$\begin{array}{c}\text { LMF_POSTCONF1 } \\
\text { minus LWFs }\end{array}$} & \multicolumn{2}{|c|}{$\begin{array}{c}\text { LMF_POSTCONF2 } \\
\text { minus LWFs }\end{array}$} \\
\hline & Difference & Test & Difference & Test & Difference & Test & Difference & Test \\
\hline \multicolumn{9}{|c|}{ Dependent Variables } \\
\hline SMTH & 0.0321 & & 0.0180 & & -0.0157 & & -0.0476 & $* * *$ \\
\hline$D A C$ & 0.0002 & & -0.0390 & $* * *$ & 0.0004 & & 0.0027 & \\
\hline$A B S D A C$ & 0.0416 & $* * *$ & 0.0169 & $* *$ & -0.0086 & & -0.0208 & $* * *$ \\
\hline DREV & 0.0195 & $* * *$ & 0.0159 & $* *$ & -0.0013 & & 0.0113 & $* *$ \\
\hline$A B S D R E V$ & 0.0351 & $* * *$ & 0.0343 & $* * *$ & -0.0018 & & -0.0095 & \\
\hline$D E X P$ & 0.0135 & $*$ & 0.0388 & $* * *$ & 0.0106 & & 0.0116 & \\
\hline$A B S D E X P$ & 0.0399 & $* * *$ & 0.0492 & $* * *$ & 0.0290 & $* *$ & -0.0110 & \\
\hline \multicolumn{9}{|c|}{ Control Variables } \\
\hline$A B S \triangle N I$ & -0.0002 & $* *$ & 0.0210 & $* * *$ & 0.0143 & $* * *$ & 0.0039 & $* * *$ \\
\hline SIZE & 0.1421 & & 0.3130 & $* *$ & 0.4203 & $* *$ & 0.4867 & $* * *$ \\
\hline$L E V L O N G$ & -0.0058 & & 0.0057 & & 0.0207 & & 0.0486 & $* * *$ \\
\hline INVREC & 0.0298 & $*$ & 0.0156 & & -0.0229 & & -0.0372 & \\
\hline GROWTH & 0.0718 & $* * *$ & -0.0266 & & -0.0225 & & -0.0339 & $* * *$ \\
\hline$R O A$ & -0.0055 & $* * *$ & -0.0145 & $* * *$ & -0.0201 & $* * *$ & -0.0163 & $* * *$ \\
\hline ETR & -0.0924 & $* * *$ & -0.3325 & $* * *$ & -0.1808 & $* * *$ & -0.1650 & $* * *$ \\
\hline REVTA & -0.1318 & $* * *$ & -0.1921 & $* *$ & -0.2342 & $* *$ & -0.2708 & $* * *$ \\
\hline$A B M A T$ & 0.0636 & $* * *$ & 0.0500 & $* * *$ & 0.0341 & $* *$ & 0.0739 & $* * *$ \\
\hline$\%$ LOSS & $-2.44 \%$ & $* * *$ & $-0.12 \%$ & & $12.68 \%$ & $* * *$ & $10.78 \%$ & $* * *$ \\
\hline \%SUSPECT & $-3.57 \%$ & $* * *$ & $-4.67 \%$ & $* *$ & $-3.98 \%$ & & $-3.72 \%$ & $* * *$ \\
\hline
\end{tabular}


Notes: The sample full period spans 2003-2012. *,** and *** denote significance levels at 10\%, 5\% and 1\%, respectively, based on a two-tailed MannWhitney-Wilcoxon test for the differences in medians of continuous variables. Pearson chi-squared test of independence for categorical variables: $\%$ LOSS $=\%$ of firms with two or more consecutive years of negative income; \%SUSPECT $=\%$ of firms just beating/meeting the zero earnings before tax benchmark. LMF_PRECONF = pre-confiscation LMF-years; LMF_CONF = LMF-years in the confiscation year; LMF_POSTCONF1 = first post-confiscation LMF-years; LMF_POSTCONF2 = LMF-years following the first post-confiscation LMF-years; $S M T H=$ earnings smoothing measure as defined in Eq. $(5)$; $D A C=$ aggregate discretionary accruals equal to residuals from Eq. (1); $A B S D A C=$ absolute value of $D A C ; D R E V=$ discretionary revenue accruals equal to residuals from Eq. (3); $A B S D R E V=$ absolute values of $D R E V ; D E X P=$ discretionary expense accruals equal to residuals from Eq. (4); $A B S D E X P=$ absolute value of $D E X P$; $A B S \triangle N I=$ absolute value of (net income - lagged net income)/ lagged total assets; SIZE = natural logarithm of total assets; $L E V L O N G=$ long-term liabilities divided by total assets; INVREC = total inventories and receivables divided by total assets; GROWTH = (total assets - lagged total assets)/ lagged total assets; $R O A=$ income before tax divided by total assets; $E T R=$ current tax expense divided by income before tax; REVTA = total revenues divided by total assets standardized by industry and year; $A B M A T=$ abnormal material expenses equal to residuals from Eq. (6). 
Table 4. Pearson correlations between independent variables

\begin{tabular}{|c|c|c|c|c|c|c|c|c|c|c|}
\hline & $A B S \triangle N I$ & $S I Z E$ & & LEVLONG & INVREC & GROWTH & $R O A$ & ETR & REVTA & $A B M A T$ \\
\hline$A B S \triangle N I$ & 1 & & & & & & & & & \\
\hline SIZE & $-0.113 * * *$ & 1 & & & & & & & & \\
\hline LEVLONG & $-0.066 * * *$ & 0.170 & $* * *$ & 1 & & & & & & \\
\hline INVREC & $-0.085 * * *$ & 0.003 & $* *$ & $-0.180 * * *$ & 1 & & & & & \\
\hline GROWTH & $0.123 * * *$ & 0.060 & $* * *$ & $0.021 * * *$ & $-0.009 * * *$ & 1 & & & & \\
\hline$R O A$ & $0.098 * * *$ & -0.105 & $* * *$ & $-0.195 * * *$ & $-0.056 * * *$ & $0.098 * * *$ & 1 & & & \\
\hline ETR & $-0.112 * * *$ & -0.038 & $* * *$ & $-0.015 * * *$ & $0.034 * * *$ & $0.010 * * *$ & $0.026 * * *$ & 1 & & \\
\hline REVTA & $0.135 * * *$ & -0.284 & $* * *$ & $-0.237 * * *$ & $0.105 * * *$ & $0.279 * * *$ & $0.215 * * *$ & $0.024 * * *$ & 1 & \\
\hline$A B M A T$ & $-0.084 * * *$ & 0.047 & $* * *$ & $0.069 * * *$ & $0.071 * * *$ & $0.041 * * *$ & $-0.191 * * *$ & $-0.019 * * *$ & $-0.046 * * *$ & 1 \\
\hline
\end{tabular}

Notes: $*, * *$ and $* * *$ denote significance levels at $10 \%, 5 \%$ and $1 \%$, respectively, based on a two-tailed test. Variables are defined in the Appendix and in the notes of Table 3 . 
Table 5. Regressions of accrual management proxies

\begin{tabular}{|c|c|c|c|c|c|c|c|c|}
\hline & \multicolumn{2}{|c|}{ SMTH } & \multicolumn{2}{|c|}{$A B S D A C$} & \multicolumn{2}{|c|}{ ABSDREV } & \multicolumn{2}{|c|}{ ABSDEXP } \\
\hline & Coef. & p-value & Coef. & p-value & Coef. & p-value & Coef. & p-value \\
\hline \multicolumn{9}{|l|}{ Variables of interest: } \\
\hline LMF_PRECONF & 0.262 & 0.013 & 0.024 & 0.015 & 0.029 & 0.000 & 0.023 & 0.000 \\
\hline (Hypothesis/Exp. Sign) & $\mathrm{H} 1 \mathrm{a} /+$ & & $\mathrm{H} 2 \mathrm{a} /+$ & & $\mathrm{H} 3 \mathrm{a} /+$ & & $\mathrm{H} 4 \mathrm{a} /+$ & \\
\hline$L M F \_C O N F$ & 0.386 & 0.134 & 0.038 & 0.005 & 0.047 & 0.007 & 0.062 & 0.007 \\
\hline (Hypothesis/Exp. Sign) & $\mathrm{H} 1 \mathrm{~b} / 0$ & & $\mathrm{H} 2 \mathrm{~b} /+$ & & $\mathrm{H} 3 \mathrm{~b} /+$ & & $\mathrm{H} 4 \mathrm{~b} /+$ & \\
\hline LMF_POSTCONF1 & 0.070 & 0.640 & -0.011 & 0.266 & 0.006 & 0.616 & 0.022 & 0.001 \\
\hline LMF_POSTCONF2 & 0.133 & 0.268 & 0.005 & 0.659 & 0.020 & 0.070 & 0.008 & 0.350 \\
\hline (Hypothesis/Exp. Sign) & $\mathrm{H} 1 \mathrm{c} / 0$ & & $\mathrm{H} 2 \mathrm{c} / 0$ & & $\mathrm{H} 3 \mathrm{c} / 0$ & & $\mathrm{H} 4 \mathrm{c} / 0$ & \\
\hline \multicolumn{9}{|l|}{ Control variables: } \\
\hline$A B S \triangle N I$ & 0.613 & 0.000 & 0.289 & 0.000 & 0.206 & 0.000 & 0.206 & 0.000 \\
\hline$S I Z E$ & -0.108 & 0.000 & -0.014 & 0.000 & -0.012 & 0.000 & -0.010 & 0.000 \\
\hline LEVLONG & -0.325 & 0.000 & -0.051 & 0.000 & -0.061 & 0.000 & -0.038 & 0.000 \\
\hline INVREC & -0.260 & 0.000 & -0.030 & 0.038 & 0.000 & 0.986 & 0.010 & 0.190 \\
\hline GROWTH & 0.211 & 0.000 & 0.110 & 0.000 & 0.080 & 0.000 & 0.078 & 0.000 \\
\hline$R O A$ & -0.203 & 0.062 & -0.045 & 0.016 & -0.037 & 0.000 & -0.069 & 0.000 \\
\hline ETR & -0.012 & 0.000 & -0.001 & 0.000 & -0.001 & 0.000 & -0.002 & 0.000 \\
\hline$R E V T A$ & 0.071 & 0.000 & 0.009 & 0.000 & 0.015 & 0.000 & 0.012 & 0.000 \\
\hline$A B M A T$ & 0.119 & 0.000 & 0.014 & 0.000 & -0.001 & 0.167 & 0.010 & 0.000 \\
\hline LOSS & -0.014 & 0.074 & 0.005 & 0.001 & -0.003 & 0.074 & 0.003 & 0.015 \\
\hline SUSPECT & 0.081 & 0.000 & 0.011 & 0.000 & 0.007 & 0.000 & 0.012 & 0.000 \\
\hline INDSEC dummies & Yes & & Yes & & Yes & & Yes & \\
\hline YEAR dummies & Yes & & Yes & & Yes & & Yes & \\
\hline Intercept & 1.082 & 0.000 & 0.411 & 0.000 & 0.252 & 0.000 & 0.237 & \\
\hline Number of obs. & 501,089 & & 534,991 & & 527,782 & & 528,552 & \\
\hline R-squared & 0.144 & & 0.188 & & 0.176 & & 0.155 & \\
\hline Wald $\chi^{2}$ & $1.79 \mathrm{E}+04$ & 0.000 & $8.70 \mathrm{E}+06$ & 0.000 & $6.70 \mathrm{E}+06$ & 0 & $2.50 \mathrm{E}+08$ & 0.000 \\
\hline
\end{tabular}

Notes: The p-values are two-tailed. Variables are defined in the Appendix and in the notes of Table 3. 
Table 6. Regressions of accrual management proxies within a matched sample

\begin{tabular}{|c|c|c|c|c|c|c|c|c|}
\hline & \multicolumn{2}{|c|}{ SMTH } & \multicolumn{2}{|c|}{$A B S D A C$} & \multicolumn{2}{|c|}{ ABSDREV } & \multicolumn{2}{|c|}{$A B S D E X P$} \\
\hline & Coef. & p-value & Coef. & p-value & Coef. & p-value & Coef. & p-value \\
\hline \multicolumn{9}{|l|}{ Variables of interest: } \\
\hline$L M F \_P R E C O N F$ & 0.279 & 0.006 & 0.024 & 0.025 & 0.028 & 0.000 & 0.025 & 0.000 \\
\hline (Hypothesis/Exp. Sign) & $\mathrm{H} 1 \mathrm{a} /+$ & & $\mathrm{H} 2 \mathrm{a} /+$ & & $\mathrm{H} 3 \mathrm{a} /+$ & & $\mathrm{H} 4 \mathrm{a} /+$ & \\
\hline LMF_CONF & 0.407 & 0.093 & 0.037 & 0.025 & 0.043 & 0.013 & 0.056 & 0.018 \\
\hline (Hypothesis/Exp. Sign) & $\mathrm{H} 1 \mathrm{~b} / 0$ & & $\mathrm{H} 2 \mathrm{~b} /+$ & & $\mathrm{H} 3 \mathrm{~b} /+$ & & $\mathrm{H} 4 \mathrm{~b} /+$ & \\
\hline LMF_POSTCONF1 & 0.099 & 0.496 & 0.000 & 0.998 & 0.018 & 0.213 & 0.021 & 0.071 \\
\hline LMF_POSTCONF2 & 0.140 & 0.240 & 0.006 & 0.634 & 0.019 & 0.070 & 0.012 & 0.168 \\
\hline (Hypothesis/Exp. Sign) & $\mathrm{H} 1 \mathrm{c} / 0$ & & $\mathrm{H} 2 \mathrm{c} / 0$ & & $\mathrm{H} 3 \mathrm{c} / 0$ & & $\mathrm{H} 4 \mathrm{c} / 0$ & \\
\hline \multicolumn{9}{|l|}{ Control variables: } \\
\hline$A B S \triangle N I$ & 0.668 & 0.197 & 0.300 & 0.000 & 0.203 & 0.001 & 0.226 & 0.000 \\
\hline SIZE & -0.155 & 0.000 & -0.019 & 0.000 & -0.014 & 0.000 & -0.016 & 0.000 \\
\hline LEVLONG & 0.062 & 0.702 & -0.008 & 0.607 & -0.058 & 0.000 & -0.018 & 0.166 \\
\hline INVREC & 0.006 & 0.943 & -0.015 & 0.308 & 0.027 & 0.088 & 0.038 & 0.000 \\
\hline GROWTH & 0.436 & 0.000 & 0.143 & 0.000 & 0.108 & 0.000 & 0.095 & 0.000 \\
\hline$R O A$ & 0.027 & 0.959 & 0.013 & 0.736 & -0.032 & 0.271 & -0.055 & 0.130 \\
\hline$E T R$ & 0.011 & 0.409 & -0.003 & 0.187 & -0.003 & 0.152 & -0.001 & 0.524 \\
\hline$R E V T A$ & 0.072 & 0.036 & 0.005 & 0.267 & 0.017 & 0.000 & 0.008 & 0.010 \\
\hline$A B M A T$ & 0.090 & 0.327 & 0.012 & 0.147 & 0.013 & 0.090 & 0.009 & 0.239 \\
\hline LOSS & -0.032 & 0.739 & -0.007 & 0.369 & -0.009 & 0.042 & -0.005 & 0.507 \\
\hline SUSPECT & 0.026 & 0.775 & 0.006 & 0.538 & 0.009 & 0.344 & 0.018 & 0.043 \\
\hline INDSEC dummies & Yes & & Yes & & Yes & & Yes & \\
\hline YEAR dummies & Yes & & Yes & & Yes & & Yes & \\
\hline Number of obs. & 3,482 & & 3,739 & & 3,615 & & 3,598 & \\
\hline R-squared & 0.103 & & 0.219 & & 0.229 & & 0.208 & \\
\hline Wald $\chi^{2}$ & $4.24 \mathrm{E}+04$ & 0.000 & $2.60 \mathrm{E}+06$ & 0.000 & $7.30 \mathrm{E}+04$ & 0 & $6.10 \mathrm{E}+05$ & 0.000 \\
\hline
\end{tabular}

Notes: The p-values are two-tailed. Variables are defined in the Appendix and in the notes of Table 3. 
Table 7. Regressions of signed accrual management proxies

\begin{tabular}{|c|c|c|c|c|c|c|}
\hline & \multicolumn{2}{|c|}{$D A C$} & \multicolumn{2}{|c|}{ DREV } & \multicolumn{2}{|c|}{ DEXP } \\
\hline & Coef. & p-value & Coef. & p-value & Coef. & p-value \\
\hline \multicolumn{7}{|l|}{ Variables of interest: } \\
\hline$L M F \_P R E C O N F$ & -0.009 & 0.370 & 0.014 & 0.200 & 0.006 & 0.478 \\
\hline LMF_CONF & -0.059 & 0.011 & 0.072 & 0.001 & 0.090 & 0.001 \\
\hline LMF_POSTCONF1 & -0.034 & 0.205 & -0.003 & 0.826 & 0.000 & 0.985 \\
\hline LMF_POSTCONF2 & 0.015 & 0.278 & 0.027 & 0.000 & 0.006 & 0.186 \\
\hline \multicolumn{7}{|l|}{ Control variables: } \\
\hline$A B S \triangle N I$ & -0.115 & 0.001 & -0.069 & 0.000 & -0.011 & 0.776 \\
\hline SIZE & -0.002 & 0.595 & 0.004 & 0.005 & 0.005 & 0.001 \\
\hline LEVLONG & 0.008 & 0.754 & -0.047 & 0.009 & -0.021 & 0.161 \\
\hline INVREC & 0.043 & 0.184 & -0.110 & 0.000 & -0.048 & 0.015 \\
\hline GROWTH & 0.156 & 0.000 & 0.262 & 0.000 & 0.178 & 0.000 \\
\hline$R O A$ & -0.025 & 0.409 & -0.074 & 0.000 & -0.007 & 0.612 \\
\hline ETR & 0.000 & 0.360 & 0.000 & 0.251 & -0.001 & 0.000 \\
\hline REVTA & -0.013 & 0.009 & -0.004 & 0.165 & -0.002 & 0.320 \\
\hline$A B M A T$ & 0.052 & 0.000 & -0.019 & 0.000 & -0.029 & 0.000 \\
\hline LOSS & -0.006 & 0.098 & -0.006 & 0.024 & 0.024 & 0.000 \\
\hline SUSPECT & 0.004 & 0.000 & 0.002 & 0.061 & 0.010 & 0.000 \\
\hline INDSEC dummies & Yes & & Yes & & Yes & \\
\hline YEAR dummies & Yes & & Yes & & Yes & \\
\hline Intercept & -0.036 & 0.403 & 0.015 & 0.545 & -0.036 & 0.048 \\
\hline Number of obs. & 534,991 & & 527,782 & & 528,552 & \\
\hline R-squared & 0.050 & & 0.184 & & 0.098 & \\
\hline Wald $\chi^{2}$ & $3.19 \mathrm{E}+04$ & 0.000 & $1.30 \mathrm{E}+06$ & 0 & $5.32 \mathrm{E}+04$ & 0.000 \\
\hline
\end{tabular}

Notes: The p-values are two-tailed. Variables are defined in the Appendix and in the notes of Table 3. 
Table 8. Regression of Dechow and Dichev's discretionary accrual proxy

\begin{tabular}{lcc} 
& \multicolumn{2}{c}{ ABSDAC_DD } \\
\hline Variables of interest: & Coef. & p-value \\
LMF_PRECONF & 0.0139 & 0.000 \\
LMF_CONF & 0.0098 & 0.213 \\
LMF_POSTCONF1 & 0.0012 & 0.793 \\
LMF_POSTCONF2 & 0.0055 & 0.175 \\
Control variables: & & \\
ABS $\triangle$ NI & 0.5728 & 0.000 \\
SIZE & -0.0015 & 0.000 \\
LEVLONG & -0.0056 & 0.000 \\
INVREC & -0.0014 & 0.375 \\
GROWTH & 0.0293 & 0.000 \\
ROA & 0.1434 & 0.000 \\
ETR & -0.0015 & 0.000 \\
REVTA & 0.0028 & 0.000 \\
ABMAT & -0.0060 & 0.000 \\
LOSS & 0.0376 & 0.000 \\
SUSPECT & 0.0109 & 0.000 \\
INDSEC dummies & Yes & \\
YEAR dummies & Yes & \\
Intercept & 0.0426 & 0.000 \\
Number of obs. & 487,817 & \\
R-squared & 0.3100 & \\
Wald $\boldsymbol{\chi}^{2}$ & $1.50 \mathrm{E}+07$ & 0.000
\end{tabular}

Notes: The p-values are two-tailed. Variables are defined in the Appendix and in the notes of Table 3. 